\title{
Chemical Analysis in Saliva and the Search for Salivary Biomarkers - A Tutorial Review
}

Kamonwad Ngamchuea, Korbua Chaisiwamongkhol, Christopher Batchelor-McAuley, Richard G. Compton*

* corresponding author: Richard G. Compton, Department of Chemistry, Physical \& Theoretical Chemistry Laboratory, University of Oxford, South Parks Road, Oxford, OX1 3QZ, United Kingdom

Emails: richard.compton@chem.ox.ac.uk

Tel: $+44(0) 1865275957 \quad$ Fax: $+44(0) 1865275410$

\begin{abstract}
Biomarkers refer to analytes that can be used in the diagnosis of diseases or disorders. In saliva, there are many components that are potential biomarkers, and an increasingly research has focussed on the development of saliva as a diagnostic fluid. This review summarizes existing uses of salivary biomarkers and highlights the importance of the choice of saliva collection as well as the storage procedures. A case study on the effect of collection tools on the concentrations of one of the potential biomarkers, glutathione, is highlighted. Moreover, molecular diagnosis requires reliable measurement assays. This review presents electroanalytical methods for the detection of salivary biomarkers. It further reviews approaches that can be taken to improve the selectivity of the electroanalytical assays without the use of biologically selective materials, notably without the use of enzymes or antibodies.
\end{abstract}




\section{Contents}

$1 \quad$ Introduction.....................................................................

2 Functions of saliva.......................................................... 4

3 Components of saliva and artificial saliva recipes............................

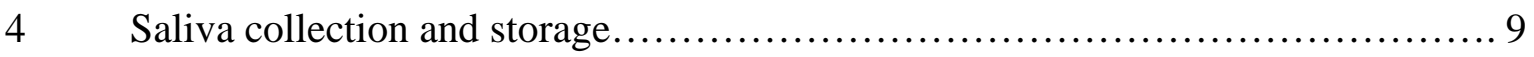

5 Biomarkers in saliva - what correlations exist, do not exist ...................... 13

$6 \quad$ Searches for biomarkers - what is needed and case histories.................... 17

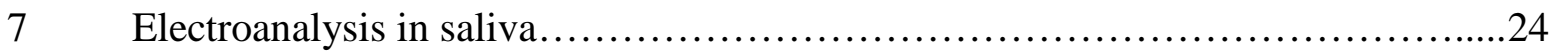

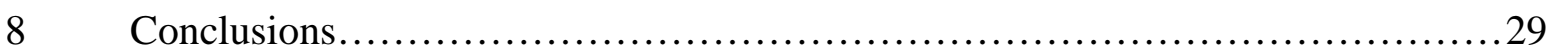

Acknowledgements........................................................... 29

References.................................................................. 30 


\section{Introduction}

Saliva is a complex bodily fluid consisting of ca. 99\% water, inorganic and organic substances and a variety of proteins such as enzymes, mucus and glycoproteins. ${ }^{1}$ It is secreted by three major pairs of salivary glands and other minor mucous glands surrounded by capillaries. ${ }^{2}$ Many blood components enter saliva via either active transport requiring chemical energy from adenosine triphosphate (ATP) or passive diffusion (no energy required; movement down a concentration gradient) through cell membranes. Accordingly, the presence, or the change in concentrations, of salivary components may be used in the diagnosis of diseases and the analysis of the state of health. Examples of commercial uses of saliva tests include HIV detection and steroid hormone monitoring.

This review focuses on salivary biomarkers i.e. diagnostically useful salivary components. Saliva testing offers advantages over blood analysis in part due to its non-invasive nature, the ease of collection, storage and shipment of specimens, as well as the possibility of collecting multiple samples. Compared with other non-invasive procedures saliva overcomes the problems of intrusion of privacy of urine and limited access to sweat and tears. Areas where saliva biomarkers may become particularly advantageous include point-of-care analysis, mass detection, epidemiologic surveillance, situations where the sample volume is limited e.g. in newborns and cases where self-monitoring may be desirable. For example in psychiatry, most diseases have persistent life-long symptoms and long-term monitoring is needed. Many neurological disorders can currently be assessed by behaviour observations as definitive causes and molecular markers are not known. Saliva tests may be able to offer alternative methods to aid the diagnosis of such diseases and disorders. Other potential uses of saliva are the detection of drugs of abuse and doping substances in forensics and sports.

A large number of publications have reported in the search for saliva biomarkers. Some focus on the development of measurement assays, while others study the correlations between the presence/absence or the levels of saliva biomarkers with specific diseases/disorders. These two areas form the basis of this review. The review starts with a short description of the functions of saliva and how salivary components play important roles in maintaining the normal functions of the body. Through understanding their functions, it is possible to investigate the potential of salivary components as biomarkers for specific diseases and disorders. Details of saliva composition are provided as a starting point for analytical chemists wanting to develop analytical assays for applications in saliva diagnosis. Also 
available recipes for artificial saliva are provided for use in the initial stage in the development of new assays. In working with real saliva samples, the importance of the careful selection of collection and storage procedures is highlighted. The review then summarizes the existing diagnostic uses of salivary biomarkers and any correlation with blood plasma and other bodily fluids. Examples of successful case histories and the important factors needed to be considered in the search for new biomarkers are then discussed. The review closes with the report of electrochemical assays for diagnostic uses. In particular, methods for improving the selectivity of the assays without the use of biologically selective molecules are considered.

\section{Functions of saliva}

There are five major functions of saliva: lubrication and protection, buffering, maintaining tooth integrity, antibacterial activity, and taste and digestion (Figure 1). ${ }^{3}$ "Lubrication and protection" preserves the oral tissues against irritating agents. The lubricating effects also help mastication, speech, and swallowing processes. The main lubricating compounds in saliva are mucins which are complex protein molecules. "Buffering action" is a second role of saliva. Whole saliva contains three major components contributing to the buffer capacity including bicarbonate, phosphate, and protein buffer. ${ }^{5}$ Enzymes such as carbonic anhydrase also participate in controlling the $\mathrm{pH}$ of saliva. ${ }^{6}$ This buffer capacity allows saliva to keep a relatively constant $\mathrm{pH}$ (normal $\mathrm{pH}$ range 6.7 - 7.3) against the acids produced by microorganisms and consumed through the diet. ${ }^{7}$ The third main function of saliva is "maintaining tooth integrity” by balancing a demineralization and a remineralization process. Demineralized processes happen when acids diffuse into the enamel resulting in crystalline dissolution and occur in a critical $\mathrm{pH}$ range (pH 5 - 5.5) for development of caries. Dissolved mineral diffuses from the tooth into the saliva. The mineral loss may be recovered to the tooth structure from ions dissolved in the saliva by remineralization process. "Anti-bacterial activity" is another important function of saliva. Saliva contains several immunologic and non-immunologic proteins with anti-bacterial properties. Among immunologic components of saliva, Secretory immunoglobulin A (IgA) is the largest proportion which can neutralize viruses, bacterial, and enzyme toxins. The non-immunologic salivary proteins also act as antibacterial agents; for example lysozyme can hydrolyze the cell wall of some bacteria. A fifth function of saliva is "taste and digestion". For a tasting function, the salivary main role includes transport of taste substances to and the protection of the taste receptors. ${ }^{9}$ The 
salivary enzyme amylase has an early role in total digestion process by breaking down starch into sugars. ${ }^{10}$

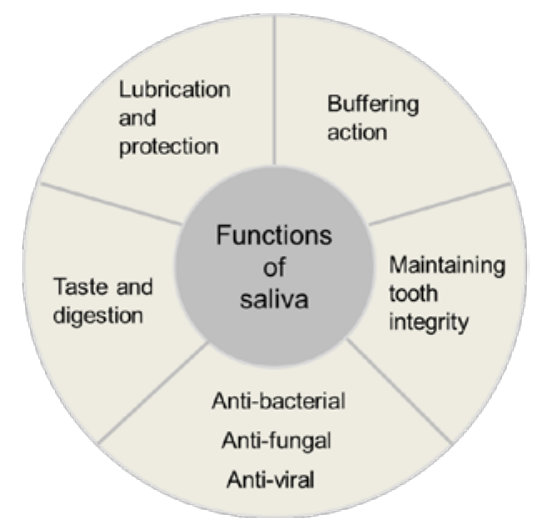

Figure 1: Main functions of saliva

\section{Components of human saliva and artificial saliva recipes}

The compositions of saliva vary during the day and between individuals. ${ }^{11}$ Attempts to report saliva constituents and concentrations mainly use average compositions that can be found in healthy subjects. Components of authentic human saliva and a comparison of the normal range of the concentrations between saliva and other biological fluids are summarized in Table 1. Briefly, saliva is composed of a variety of ions including sodium, potassium, calcium, bicarbonate, thiocyanate and phosphate. Also found in saliva are low molecular weight organic substances such as uric acid and lactate, immunoglobulins, enzymes, mucins and some important hormones such as cortisol.

In research studies, the use of natural saliva is limited as it is difficult to collect and sterilize a large amount of saliva. Moreover, saliva samples vary in composition and properties. ${ }^{12}$ Accordingly, synthetic saliva was developed for use in in vitro studies. A basic requirement of synthetic saliva is to react in the system or with the test material in the same manner to that of authentic saliva. However, it is well understood that an exact duplication of human saliva properties is impossible owing to the inconsistent and unstable nature of authentic saliva which vary during the day and within every individual as mentioned earlier. ${ }^{13}$ Many synthetic saliva recipes can be found in the literature as reviewed by Leung et al. ${ }^{13}$ who collected several formulae published between 1931 and 1997. 
This review presents five different synthetic saliva recipes as developed for different purposes. The selected artificial saliva formulae are frequently used by others with or without modification of the proposed recipe. As shown in Table 2, some of these formulae include exclusively inorganic compounds which are used for in vitro studies, ${ }^{14-18}$ whereas others include some organic compounds and proteins. ${ }^{12,} 19$ For AFNOR, Fusayama-Meyer and SAGF recipes, these three formulae include only inorganic compositions which are more or less similar to an average composition of human saliva. The composition was also chosen based on the similarity of experimental results obtained from the artificial saliva and from the authentic human saliva. ${ }^{16}$ The proposed recipes were employed in the study of electrochemical behaviour and corrosion resistance of materials in dental applications. ${ }^{14-18}$ The organic components and some proteins are responsible for saliva viscosity and as such might influence the diffusion rates of other solutes, and thus some reaction rates. Note that the viscosity of human whole saliva is ca. 1.30 relative to distilled water. ${ }^{20}$ For saliva samples that have been centrifuged and filtrated to remove viscous components, the viscosity reduces to being close to that of distilled water. In developing artificial saliva for chemical and electrochemical researches, there is no attempt to simulate the viscosity of authentic saliva owing to the practical difficulty of obtaining suitable materials. Therefore, most electrochemical studies included only inorganic compositions of artificial saliva. For biological studies, organic components and proteins are necessary to mimic medium as closely as possible for the use of in vitro model systems to study dental biofilms. For example, in the cultural studies of dental plaque reported by Shellis, ${ }^{12}$ the first step in an artificial saliva preparation was the extraction of the salivary glycoproteins from bovine submandibular glands. 
Table 1

Components of authentic human saliva and a comparison of the normal range of the concentrations between saliva and other biological fluids

\begin{tabular}{|c|c|c|c|c|}
\hline \multirow{2}{*}{\multicolumn{2}{|c|}{ Real saliva compositions }} & \multicolumn{2}{|c|}{ Normal range } & \multirow{3}{*}{$\begin{array}{c}\text { Ref } \\
11\end{array}$} \\
\hline & & \multirow{2}{*}{$\begin{array}{r}\text { Saliva } \\
20-80 \mathrm{mmol} / \mathrm{L}\end{array}$} & \multirow{2}{*}{$\begin{array}{l}\text { Other biological fluids } \\
\text { Plasma } 145 \mathrm{mmol} / \mathrm{L}\end{array}$} & \\
\hline \multirow[t]{9}{*}{ 1. Inorganic compounds } & $\mathrm{Na}^{+}$ & & & \\
\hline & $\mathrm{K}^{+}$ & $20 \mathrm{mmol} / \mathrm{L}$ & $4 \mathrm{mmol} / \mathrm{L}$ & \\
\hline & $\mathrm{Ca}^{2+}$ & $1-4 \mathrm{mmol} / \mathrm{L}$ & $2.2 \mathrm{mmol} / \mathrm{L}$ & \\
\hline & $\mathrm{Cl}^{-}$ & $30-100 \mathrm{mmol} / \mathrm{L}$ & $120 \mathrm{mmol} / \mathrm{L}$ & \\
\hline & $\mathrm{HCO}_{3}^{-}$ & $15-80 \mathrm{mmol} / \mathrm{L}$ & $25 \mathrm{mmol} / \mathrm{L}$ & \\
\hline & Phosphate & $4 \mathrm{mmol} / \mathrm{L}$ & $1.2 \mathrm{mmol} / \mathrm{L}$ & \\
\hline & $\mathrm{Mg}^{2+}$ & $0.2 \mathrm{mmol} / \mathrm{L}$ & $1.2 \mathrm{mmol} / \mathrm{L}$ & \\
\hline & $\mathrm{SCN}^{-}$ & $2 \mathrm{mmol} / \mathrm{L}$ & $<0.2 \mathrm{mmol} / \mathrm{L}$ & \\
\hline & $\mathrm{NH}_{3}$ & $3 \mathrm{mmol} / \mathrm{L}$ & $0.05 \mathrm{mmol} / \mathrm{L}$ & \\
\hline \multirow{11}{*}{$\begin{array}{l}\text { 2. Organic compounds (non-protein } \\
\text { and lipids) }\end{array}$} & \multirow[t]{3}{*}{ Uric acid } & $3.38 \pm 0.21 \mathrm{mg} / \mathrm{dL}$ & Serum $6.31 \pm 0.24 \mathrm{mg} / \mathrm{dL}$ & \multirow[t]{3}{*}{$21-23$} \\
\hline & & $217.2 \pm 110.3 \mathrm{~mol} / \mathrm{L}$ & & \\
\hline & & $0.1-7.5 \mathrm{mg} / \mathrm{dL}$ & & \\
\hline & Bilirubin & $0.5-5.0 \mu \mathrm{mol} / \mathrm{L}$ & Serum 0.2-1.2 mg/dL & 24 \\
\hline & \multirow[t]{2}{*}{ Creatinine } & $0.12 \pm 0.06 \mathrm{mg} / \mathrm{dL}$ & $\begin{array}{l}\text { Serum } 0.89 \pm 0.17 \\
\mathrm{mg} / \mathrm{dL}\end{array}$ & \multirow[t]{2}{*}{25} \\
\hline & & $0.05-0.2 \mathrm{mg} / \mathrm{dL}$ & Serum $0.6-1.5 \mathrm{mg} / \mathrm{dL}$ & \\
\hline & \multirow[t]{2}{*}{ Glucose } & $91.3 \pm 10.1 \mathrm{mg} / \mathrm{dL}$ & Plasma $80-120 \mathrm{mg} / \mathrm{dL}$ & \multirow[t]{2}{*}{22,26} \\
\hline & & $4-13 \mathrm{mg} / \mathrm{dL}$ & & \\
\hline & Cholesterol & $0.02-5.46 \mu \mathrm{mol} / \mathrm{L}$ & Serum $<5 \mathrm{mmol} / \mathrm{L}$ & 27 \\
\hline & \multirow[t]{2}{*}{ Lactate } & $0.3-1.8 \mathrm{mM}$ & Serum $0.5-1.0 \mathrm{mM}$ & \multirow[t]{2}{*}{28,29} \\
\hline & & 0.1 to $2.5 \mathrm{mmol} / \mathrm{L}$ & & \\
\hline \multirow[t]{12}{*}{ 3. Protein/Polypeptide compounds } & \multirow[t]{3}{*}{ a-Amylase } & $19-308 \mathrm{U} / \mathrm{mL}^{*}$ & $\begin{array}{l}\text { Serum } 0.05-0.125 \\
\mathrm{U} / \mathrm{mL}^{*}\end{array}$ & \multirow[t]{3}{*}{23,30} \\
\hline & & $93 \pm 62 \mathrm{U} / \mathrm{L} *$ & & \\
\hline & & $2.64 \pm 1.8 \mathrm{mg} / \mathrm{mL}$ & & \\
\hline & Albumin & $0.2 \pm 0.1 \mathrm{mg} / \mathrm{mL}$ & Serum 3.5-5.5 g/dL & 31 \\
\hline & \multirow[t]{2}{*}{ Secretory-IgA } & 80-717 mg/dL & Serum 70-400 mg/dL & \multirow[t]{2}{*}{23,32} \\
\hline & & $124.3-333.5 \mu \mathrm{g} / \mathrm{mL}$ & & \\
\hline & \multirow[t]{2}{*}{ Mucins group } & MUC5B: $2.4 \pm 1.7 \mathrm{U} / \mathrm{mL}$ & Serum $9.9 \pm 0.8 \mathrm{ng} / \mathrm{ml}$ & \multirow[t]{2}{*}{31,33} \\
\hline & & $1.19 \pm 0.17 \mathrm{mg} / \mathrm{mL}$ & & \\
\hline & \multirow[t]{2}{*}{ Lysozyme } & $3-50 \mu \mathrm{g} / \mathrm{mL}$ & Serum $7.4 \pm 1.8 \mathrm{mg} / \mathrm{mL}$ & \multirow{2}{*}{$\begin{array}{c}23,32, \\
34\end{array}$} \\
\hline & & 59.7 to $1062.3 \mu \mathrm{g} / \mathrm{ml}$ & Serum 4-9 $\mu \mathrm{g} / \mathrm{mL}$ & \\
\hline & \multirow[t]{2}{*}{ Total proteins } & $7.1-223.2 \mathrm{mg} / \mathrm{dL}$ & Serum 6-8 g/dL & \multirow[t]{2}{*}{23,31} \\
\hline & & $0.9 \pm 0.2 \mathrm{mg} / \mathrm{mL}$ & & \\
\hline \multirow[t]{6}{*}{ 4. Hormones } & Cortisol & $3.5-27.0 \mathrm{mg} / \mathrm{dL}$ & Serum 2-25 mg/dL & 35 \\
\hline & Testosterone & $32-55 \mathrm{pg} / \mathrm{mL}$ & Serum 320-600 ng/dL & 36 \\
\hline & Progesterone & $\begin{array}{l}\text { Luteal phase } 436 \pm 34 \\
\mathrm{pmol} / \mathrm{L}\end{array}$ & Serum Male: < $1 \mathrm{ng} / \mathrm{mL}$ & 37 \\
\hline & & $\begin{array}{l}\text { Follicular phase } 22.1 \pm 2.7 \\
\mathrm{pmol} / \mathrm{L}\end{array}$ & $\begin{array}{l}\text { Serum Female: } 0.1-20 \\
\mathrm{ng} / \mathrm{mL}\end{array}$ & \\
\hline & $\begin{array}{l}\text { Estrogen(Estra } \\
\text { diol) }\end{array}$ & $\begin{array}{l}\text { Luteal phase } 20.6 \pm 0.4 \\
\mathrm{pmol} / \mathrm{L}\end{array}$ & $\begin{array}{l}\text { Serum Male: } 15-60 \\
\text { pg/mL }\end{array}$ & 37 \\
\hline & & & $\begin{array}{l}\text { Serum Female: } 15-370 \\
\mathrm{pg} / \mathrm{mL}\end{array}$ & \\
\hline
\end{tabular}

*U/mL: enzymatic activity per unit (mL) of saliva 
Table 2

Compositions of different artificial saliva recipes

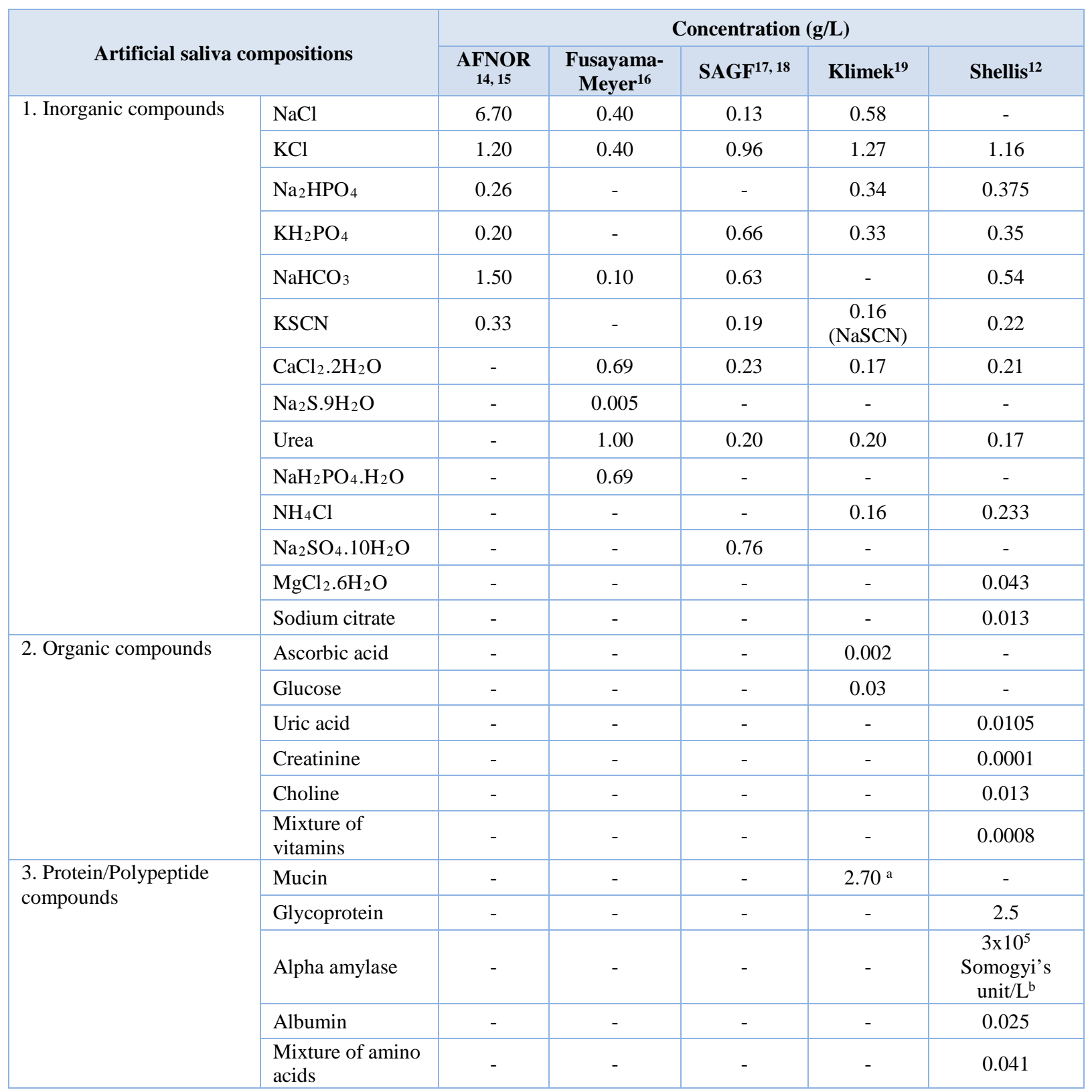

${ }^{\text {a }}$ Bacto-Mucin Bacteriological

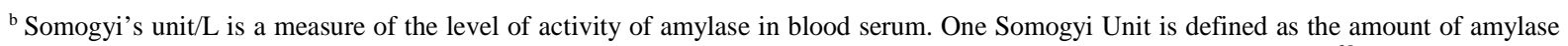
required to produce the equivalent of $1 \mathrm{mg}$ of glucose when acting on a standard starch solution under defined condition. ${ }^{38}$ 


\section{$4 \quad$ Saliva collection and storage}

Successful measurement of target analytes in saliva requires suitable collection, processing, and storing under suitable conditions. ${ }^{39}$ Saliva samples can be easily collected from humans. Collection of saliva can be generally categorized into two groups: whole saliva collection and individual gland collection. Whole saliva is simple to collect and does not need to be performed by specialists but can be done by study subjects or patients. Unstimulated whole saliva can be readily obtained by 'passive drooling' or 'spitting' directly into a container. ${ }^{40,41}$ Stimulated whole saliva can be collected through mechanical stimulation by chewing inert materials such as parafilm and/or gustatory stimulation with acid i.e. $0.01 \mathrm{M}$ citric acid. Briefly, for citric acid use, cotton soaked with citric acid was placed on the back of the tongue for a period of time i.e. $30 \mathrm{sec}$ and then was removed. The stimulated whole saliva was then collected into a container. ${ }^{42}$ Note that the use of citric acid lessens the $\mathrm{pH}$ of samples to below 3 so it is apparent that the use of citric acid stimulation is not suitable for obtaining samples for $\mathrm{pH}$ measurement in saliva. Moreover, citric use may also have an effect on the measurement of some analytes such as testosterone and electrolyte concentrations. ${ }^{43,44}$ There are some devices that facilitate the stimulated collection of whole saliva. Most of them comprise cotton based material for saliva adsorption and a conical tube for centrifugation and retrieval of collected saliva. Note however that cotton based sampling may affect some of the salivary composition levels because of the binding of analytes to cotton. ${ }^{45}$ In order to avoid the binding of analytes to the collection devices, non-cotton based materials such as polystyrene and polyester are preferable. ${ }^{46}$

Herein, we present a case study from the authors' laboratory to demonstrate the effects of the collection tools on the concentration of glutathione (GSH) detected. In particular, the differences between cotton and polystyrene swabs are investigated using standard glutathione solutions and real saliva samples. The importance of glutathione and its potential as a biomarker will be discussed later in the following section.

In the case of standard solutions, $1 \mu \mathrm{M}$ of GSH in phosphate buffer $\mathrm{pH} 7.0$ was used. First, the GSH solution with the initial volumes of 245,980 or $1,960 \mu \mathrm{L}$ was exposed to cotton Salivette ${ }^{\circledR}$ swab. The solution was left on the cotton swab for a varied time between 0 - 60 min. The soaked cotton swab was then centrifuged at the supplier recommended speed of $1000 \mathrm{~g}$ for $1 \mathrm{~min}$. The extracted liquid, whose volume was smaller than the initial volume, 
was then subjected to GSH measurement by the modified Tietze method. ${ }^{47}$ The amount of GSH recovered from the swab is quantified by the percentage (\%) recovery defined as:

$$
\% \text { recovery }=\left(c_{\mathrm{f}}-c_{\mathrm{i}}\right) / c_{\mathrm{i}} \times 100 \%
$$

where $c_{\mathrm{i}}$ and $C_{\mathrm{f}}$ refer to the concentrations of glutathione measured before and after being exposed to the swabs respectively.

Figure 2a shows that the recovery of GSH from cotton swab is always lower than $100 \%$, even in the case that the Salivettes are centrifuged immediately after collection. Figure 2a also demonstrates the decrease of glutathione recovery as a function of exposure time $(t)$, with only ca. $20 \%$ of GSH recovered in the worst case $(245 \mu \mathrm{L}$ initial volume and $60 \mathrm{~min}$ exposure time). In real applications where there is unavoidable varying delay in the transfer of samples from collection points such as clinic or hospital to the analysis laboratory, the delay can give rise to significant errors.

From Figure 2a, it can also be seen that the percentage recovered from the cotton swabs also depends on the initial volumes used. The dependency on the initial volume makes it not possible to correct for the loss of GSH, especially in saliva collection experiments where initial volumes are unknown. Consequently, the use of cotton-based tool induces random errors to saliva analysis especially for substances which have high affinity to bind to cotton. As a comparison to the cotton Salivette ${ }^{\circledR}$, synthetic polystyrene Salivette ${ }^{\circledR}$ was studied. In contrast to the cotton, polystyrene yields ca. $100 \%$ recovery of the material (Figure $2 \mathrm{~b}$ ), suggesting that polystyrene may be a better alternative for saliva collection.

The effect of the collection tools on the concentrations of glutathione detected was further investigated in real saliva samples. The subjects were given the cotton and polystyrene swabs to chew for $1 \mathrm{~min}$. The stimulated saliva samples were then extracted from the swabs by centrifuging at $1000 \mathrm{~g}$ for $1 \mathrm{~min}$. Whole unstimulated saliva collected by spitting were also studied in comparison. As glutathione concentrations vary from sample to sample, the results are presented as 'normalized GSH concentration' where the GSH concentration in whole unstimulated saliva is normalized to 1, and the GSH levels in stimulated saliva collected from the same subject are scaled accordingly. When collecting stimulated saliva using the cotton Salivette ${ }^{\circledR}$, the glutathione measured were $81 \pm 2 \%(t=0 \mathrm{~min})$ and $83 \pm 7 \%(t=10 \mathrm{~min})$ of that detected in unstimulated saliva (Figure 2c). On the other hand when polystyrene Salivette was used, the levels of GSH detected were $101 \pm 8 \%(t=0 \mathrm{~min})$ and $107 \pm 6 \%(t=10 \mathrm{~min})$ 
of the whole unstimulated saliva level (Figure 2c). The comparable results in whole unstimulated saliva and stimulated saliva obtained using polystyrene Salivette ${ }^{\circledR}$ further evidence that polystyrene swab is a suitable saliva collection tool for glutathione analysis. However, note that this may not be the case for some other analytes as they may be able to adsorb onto polystyrene, and hence the effect of the collection tools on the recovery of analytes should be studied prior to any real saliva applications. It is of note that in some cases, the levels of analytes in unstimulated and stimulated saliva may not be expected to be the same even if the material is not lost to the collection tool. This difference between the stimulated and unstimulated saliva may occur when the analyte's concentration is affected by the change in flow rates or the different contributions of saliva glands. ${ }^{48}$

GSH in phosphate buffer $\mathrm{pH} 7.0$

Real saliva samples

a)

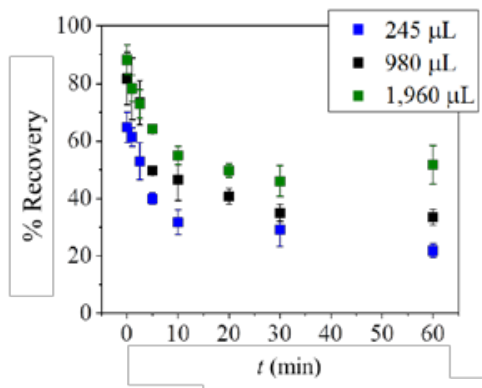

b)

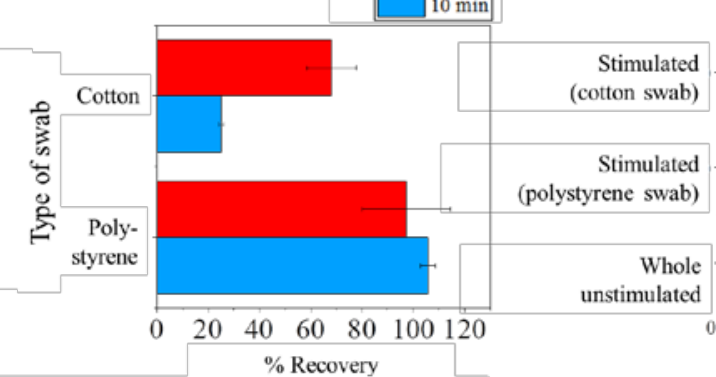

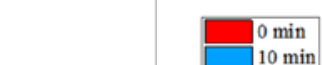

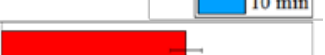

Figure 2: The effects of collection tools on the recovery of glutathione. a) The amount of glutathione recovered from cotton swab as a function of time between collection and centrifugation retrieval of the samples. b) The bar graph showing the significantly higher recovery of glutathione from synthetic polystyrene Salivette ${ }^{\circledR}$ as compared with cotton Salivette ${ }^{\circledR}$ at two different exposure times $(t)$ of $0 \mathrm{~min}$ (red) and $60 \mathrm{~min}$ (blue). c) The concentrations of glutathione in real saliva samples: whole unstimulated saliva collected by spitting directly into a container and stimulated saliva collected by cotton Salivette ${ }^{\circledR}$ and polystyrene Salivette ${ }^{\circledR}$ at two different exposure times $(t)$ of 0 min (red) and 10 min (blue).

In the above, we have reviewed the available methods for whole saliva collection and the potential problems associated with the use of cotton-based collection tools, next we will discuss individual gland collection. Individual gland saliva can be obtained by glandular ducts cannulation (a thin tube inserted into a duct to obtain saliva) or by using specific collecting devices to the ducts of interest. For example, pure parotid saliva may be collected by the use of a metal or acrylic cup placed over the Stenson's duct. ${ }^{49}$ However, from a 
practical viewpoint, these sampling procedures are slow and complex, and require a specialist for collecting the specimens. For these reasons, these collection methods are not widely used.

It is also important to use an appropriate container for the target analytes. For example, if target analytes are steroid hormones, such as cortisol, low-affinity plastic containers should be used to prevent protein binding to the walls of collection tubes. ${ }^{50}$ For these reasons, the nature of the compounds of interest must be always taken into account when designing sampling approaches.

After collection, saliva samples should be rapidly processed or suitably stored. Some salivary components are stable in saliva for a long time, while others have very short lifetimes. Inorganic compounds are relatively stable at room temperature. Czegeny et al. ${ }^{51}$ reported that calcium and magnesium contents showed good stability for at least 1 week when the samples were stored at room temperature. Moreover, calcium and phosphate were found to be stable when stored at $-20^{\circ} \mathrm{C}$ for up to two months. ${ }^{52}$ On the other hand, cortisol (steroid hormone) level decreased by ca. $10 \%$ per month in samples stored at room temperature. ${ }^{53}$ Cortisol is stable in saliva for up to three months at $5^{\circ} \mathrm{C}$ and up to one year at $-20^{\circ} \mathrm{C}$ and $-80^{\circ} \mathrm{C}$. Proteins also showed rapid degradation within 30 min after sample collection at room temperature. ${ }^{54}$ Storing of the samples at $4^{\circ} \mathrm{C}$ and the use of protease inhibitors can help reduce degradation. $^{54}$

An alternative approach to preserve target analytes in saliva samples is the pre-analytical treatment of the samples prior to storage. For example, snap-freezing of saliva with glycerol in liquid nitrogen is a method for inhibiting bacterial protease activity from degrading some proteins in saliva. The method was used by Nurkka et al. ${ }^{55}$ for storing saliva before testing anticapsular IgA concentrations. Briefly, the saliva specimen was mixed with an equal volume of $80 \%$ glycerol in $\mathrm{H}_{2} \mathrm{O}$ and dipped into liquid nitrogen. This approach yielded an antibody concentration ca. $50 \%$ higher than that in specimens temporarily stored at $4^{\circ} \mathrm{C}$ (whether or not the sample was stored with protease inhibitors). Another possible method for pre-treatment is to mix saliva with enzyme inhibitors, stabilizing substances and/or sodium azide $\left(\mathrm{NaN}_{3}\right)$ to delay bacterial growth. Gröschl et al. ${ }^{56}$ demonstrated that added sodium azide stabilized the concentrations of salivary steroids (cortisol and progesterone). However, sodium azide can interfere with the activity of horseradish peroxidase which is a common component in enzyme-based saliva immunoassays. ${ }^{57}$ Therefore if pre-treatment is used, any 
interferences caused by added compounds to the measurement assays and to other salivary components have to be thoroughly investigated.

\section{$5 \quad$ Biomarkers in saliva - what correlations exist, do not exist}

Prior to diagnostic use, the applicability of the biomarkers for a specific disease has to be validated. Ideally, the aetiology of the disease - that is the mechanisms by which the biomarker takes part in the development of diseases or the action of the biomarker during the diseases - should be understood. However, the mechanistic detail is often unknown or not adequately known. Hence, the relevance of the biomarker to a specific disease has to be investigated based on a statistical model..$^{58}$

The potential of a salivary component as a biomarker may be evaluated by the correlation of the presence/absence or the concentrations of the biomarker in saliva samples between a control population and the patients. Additionally, it is recommended that the correlation between matched blood plasma and saliva samples is investigated alongside the correlation with diseases. In general, the ratio of the concentrations in plasma to saliva should be approximately constant, otherwise the factors influencing the ratios should be examined. ${ }^{59}$

Hitherto, the potential of salivary inorganic constituents, anti-oxidants, hormones, antibodies and antigens as biomarkers in the diagnosis of several oral and systemic diseases have been recognized. In oral diseases, saliva has been used to detect oral cavity cancer, dental caries, periodontal disease and oral dryness; see Table 3. In systemic diseases (i.e. diseases that affect the entire body), saliva has been demonstrated to have strong correlations with plasma or serum for many cell components, and hence can act as a mirror reflecting the health states of the body. ${ }^{60}$ Examples of reported uses of saliva in systemic conditions, diseases, disorders and infections include the monitoring of hormone levels, pregnancy, risks for preterm labour, psychological disorders, neurological disorders, the condition of the immune system, smoking status, virus infections and nutritional status (Table 3).

It has also been shown that therapeutic drugs and drugs of abuse can be detected in saliva, the levels of which exhibit strong correlations with those in plasma or serum. In addition to providing an alternative choice of specimen for drug monitoring, the ability to detect therapeutic drugs in saliva allows the studies of pharmacokinetics and facilitates individualization of pharmacotherapy as multiple non-invasive saliva samples can be readily 
collected. The saliva tests of drugs of abuse and prohibited doping substances provide convenient, accessible and lower cost methods for vehicle checkpoints, quarantine stations, sport competitions and in other screening tests. Table 3 provides examples of the current diagnostic uses of salivary biomarkers, together with any correlations with serum, plasma and other bodily fluids.

Note that the correlation between two sets of data may be determined by the Pearson correlation coefficient $(r)$ and/or the p-value (p). The former measures the linear relationship between two random variables. ${ }^{61}$ The positive value of $r$ means that when the value of one parameter increases, it is likely the value of the other parameter will also increase. The higher magnitude of $r(|r| \leq 1)$, the greater probability that this is true. For example, $r=0$ : no correlation, $r=+0.5$ : moderately positive correlation, $r=+0.8$ : strong positive correlation and $r=+1$ : perfectly positive correlation. In Table 3, all correlations presented refer to positive correlations. Alternatively, the correlation may be assessed by the p-value which is based on hypothesis testing. ${ }^{62,} 63$ First, a null hypothesis $\left(\mathrm{H}_{0}\right)$ is assumed. For example in the correlation studies, the null hypothesis is that there is no correlation between the two sets of data. The p-value quantifies the possibility that the null hypothesis is true. The lower the pvalue, the more likely we can reject the null hypothesis. If p-value is smaller than the designated significant level $(\alpha)$ of usually $0.05, \mathrm{H}_{0}$ is rejected with less than $5 \%$ chance that this is the incorrect rejection of $\mathrm{H}_{0}$. In other words, usually when $\mathrm{p}<0.05$, the correlation is considered to be statistically significant. Note the difference between strong correlation which is based on ' $r$ ' and significant correlation which is based on ' $p$.' 
Table 3 Examples of the diagnostic uses of salivary biomarkers and their correlations with blood plasma, serum and other bodily fluids

\begin{tabular}{|c|c|c|c|c|c|}
\hline Biomarkers & Diagnostic uses & Bodily fluid(s) & Correlation & Detection method & [Ref] \\
\hline \multicolumn{6}{|c|}{ Chemicals } \\
\hline \multirow[t]{2}{*}{ Cotinine } & cigarette usage & saliva / plasma & $\begin{array}{l}\text { strong correlation } \\
(r=0.99)\end{array}$ & GC & 64 \\
\hline & cigarette usage & saliva / serum & strong correlation & HPLC/ MS & 65 \\
\hline \multirow[t]{2}{*}{ Nicotine } & cigarette usage & saliva / urine & - & $\begin{array}{l}\text { single-drop } \\
\text { microextraction / GC- } \\
\text { FID }\end{array}$ & 66 \\
\hline & $\begin{array}{l}\text { nicotine skin patch } \\
\text { users }\end{array}$ & $\begin{array}{l}\text { stimulated saliva / } \\
\text { plasma }\end{array}$ & $\begin{array}{l}\text { strong correlation } \\
(r=0.82)\end{array}$ & - & 67 \\
\hline Anabasine & cigarette usage & saliva / urine & - & $\begin{array}{l}\text { single-drop } \\
\text { microextraction / GC- } \\
\text { FID }\end{array}$ & 66 \\
\hline \multirow[t]{2}{*}{ Nitrates and nitrites } & gastric cancer & saliva & - & colorimetric & 68 \\
\hline & periodontal disease & $\begin{array}{l}\text { stimulated / } \\
\text { unstimulated saliva }\end{array}$ & - & colorimetric & 69 \\
\hline \multirow[t]{3}{*}{ Caffeine } & $\begin{array}{l}\text { caffeine clearance: } \\
\text { liver function }\end{array}$ & saliva / serum & $\begin{array}{l}\text { strong correlation } \\
(r>0.98)\end{array}$ & enzyme immunoassay & 70 \\
\hline & probe for CYP1A2 & $\begin{array}{l}\text { saliva / plasma } \\
\text { /urine }\end{array}$ & $\begin{array}{l}\text { strong correlation } \\
\text { with plasma } \\
(r=0.97)\end{array}$ & - & 71 \\
\hline & drug monitoring & saliva / plasma & $\begin{array}{l}\text { strong correlation } \\
(r=0.98)\end{array}$ & HPLC & 72,73 \\
\hline \multirow[t]{2}{*}{$\mathrm{SCN}^{-}$} & smoking status & $\begin{array}{l}\text { saliva / plasma / } \\
\text { urine }\end{array}$ & - & colorimetric & 74 \\
\hline & cystic fibrosis & saliva & - & colorimetric & 75 \\
\hline \multicolumn{6}{|c|}{ Anti-oxidants } \\
\hline \multirow[t]{4}{*}{ Glutathione (GSH, GSSG) } & $\begin{array}{l}\text { head and neck } \\
\text { squamous cell } \\
\text { carcinoma (GSH) }\end{array}$ & stimulated saliva & - & HPLC & 76 \\
\hline & $\begin{array}{l}\text { oral squamous Cell } \\
\text { carcinoma (GSH) }\end{array}$ & unstimulated saliva & - & colorimetric & 77 \\
\hline & $\begin{array}{l}\text { health monitoring } \\
\text { (GSH + GSSG) }\end{array}$ & $\begin{array}{l}\text { stimulated saliva / } \\
\text { whole blood }\end{array}$ & $\begin{array}{l}\text { weak correlation } \\
(r=0.43)\end{array}$ & colorimetric & 47 \\
\hline & $\begin{array}{l}\text { diabetic / parenteral } \\
\text { drug addict (GSH, } \\
\text { GSSG) }\end{array}$ & stimulated saliva & - & fluorometric & 78 \\
\hline Ascorbic acid & correlation studies & $\begin{array}{l}\text { parotid saliva / } \\
\text { plasma / white blood } \\
\text { cell (WBC) }\end{array}$ & $\begin{array}{l}\text { significant } \\
\text { correlation with } \\
\text { WBC }(p<0.001)\end{array}$ & - & 79 \\
\hline \multirow[t]{4}{*}{ Uric acid } & oral cavity cancer & saliva & - & colorimetric & 80 \\
\hline & gout & saliva / blood & - & colorimetric & 81 \\
\hline & diabetes & saliva / serum & - & colorimetric & 82 \\
\hline & metabolic syndrome & saliva & - & colorimetric & 83 \\
\hline \multicolumn{6}{|c|}{ Therapeutic drugs } \\
\hline \multirow{2}{*}{$\begin{array}{l}\text { Anticonvulsants / } \\
\text { antiepileptic }\end{array}$} & drug monitoring & saliva / plasma & strong correlation & GLC, immunoassay & $84-86$ \\
\hline & drug monitoring & $\begin{array}{l}\text { saliva / plasma / } \\
\text { cerebrospinal fluid }\end{array}$ & strong correlation & GC-FID & 87 \\
\hline \multirow[t]{2}{*}{ Theophylline } & drug monitoring & $\begin{array}{l}\text { stimulated saliva / } \\
\text { plasma }\end{array}$ & $\begin{array}{l}\text { strong correlation } \\
(r>0.9)\end{array}$ & HPLC, immunoassay & $88-90$ \\
\hline & drug monitoring & $\begin{array}{l}\text { unstimulated (U), } \\
\text { stimulated (S) saliva } \\
\text { / plasma }\end{array}$ & $\begin{array}{l}\text { strong correlation } \\
(\mathrm{U}: r=0.97) \\
(\mathrm{S}: r=0.88)\end{array}$ & immunoassay & 91 \\
\hline $\begin{array}{l}\text { Acetaminophen } \\
\text { (paracetamol) }\end{array}$ & drug monitoring & $\begin{array}{l}\text { whole saliva / } \\
\text { plasma }\end{array}$ & $\begin{array}{l}\text { strong correlation } \\
(r=0.95)\end{array}$ & colorimetric & 92 \\
\hline \multirow[t]{2}{*}{ Lithium } & drug monitoring & saliva / serum & $\begin{array}{l}\text { strong correlation } \\
(r=0.83)\end{array}$ & - & 93 \\
\hline & drug monitoring & $\begin{array}{l}\text { stimulated saliva / } \\
\text { plasma / RBC }\end{array}$ & strong correlation & flame photometry & 94 \\
\hline
\end{tabular}




\begin{tabular}{|c|c|c|c|c|c|}
\hline Biomarkers & Diagnostic uses & Bodily fluid(s) & Correlation & Detection method & [Ref] \\
\hline \multicolumn{6}{|c|}{ Drugs of abuse } \\
\hline Ethanol & drug monitoring & $\begin{array}{l}\text { saliva / serum, whole } \\
\text { blood / urine }\end{array}$ & strong correlation & GC-FID, colorimetric & $95-98$ \\
\hline Cocaine & drug monitoring & saliva / plasma & $\begin{array}{l}\text { significant } \\
\text { correlation } \\
(\mathrm{p} \leq 0.05)\end{array}$ & - & 99,100 \\
\hline Heroin & drug monitoring & saliva / plasma & - & GC-MS, immunoassay & 101-103 \\
\hline Marijuana & drug monitoring & saliva & - & $\begin{array}{l}\text { fluorometric, } \\
\text { immunoassay }\end{array}$ & 104,105 \\
\hline \multicolumn{6}{|c|}{ Prohibited doping substances } \\
\hline $\begin{array}{l}\text { Amphetamine, metham- } \\
\text { phetamine, etc.* }\end{array}$ & detection & saliva / urine & - & GC-MS & 106 \\
\hline \multicolumn{6}{|c|}{ Hormones } \\
\hline \multirow[t]{3}{*}{ Cortisol } & $\begin{array}{l}\text { chronic fatigue } \\
\text { syndrome, depression }\end{array}$ & saliva / plasma & strong correlation & immunoassay & 107,108 \\
\hline & $\begin{array}{l}\text { evaluation of adrenal } \\
\text { function }\end{array}$ & $\begin{array}{l}\text { saliva / plasma / } \\
\text { serum }\end{array}$ & strong correlation & immunoassay & 109,110 \\
\hline & correlation studies & saliva / serum & $\begin{array}{l}\text { strong correlation } \\
(r=0.89)\end{array}$ & immunoassay & 111 \\
\hline Aldosterone & correlation studies & saliva / plasma & $\begin{array}{l}\text { strong correlation } \\
\left(r=0.84,{ }^{112} 0.93^{113}\right)\end{array}$ & dialysis, immunoassay & 112 \\
\hline \multirow[t]{2}{*}{ Testosterone } & correlation studies & saliva / plasma & $\begin{array}{l}\text { strong correlation } \\
(r>0.7)\end{array}$ & dialysis, immunoassay & 114,115 \\
\hline & correlation studies & saliva / serum & $\begin{array}{l}\text { strong correlation } \\
(r>0.8)\end{array}$ & immunoassay & 116,117 \\
\hline \multirow[t]{2}{*}{ 17-hydroxyprotesterone } & $\begin{array}{l}\text { assessing endocrine } \\
\text { function }\end{array}$ & $\begin{array}{l}\text { saliva / plasma / } \\
\text { parotid fluid }\end{array}$ & $\begin{array}{l}\text { strong correlations } \\
(r>0.9)\end{array}$ & immunoassay & 118 \\
\hline & $\begin{array}{l}\text { 21-Hydroxylase } \\
\text { deficiency }\end{array}$ & saliva / serum & $\begin{array}{l}\text { strong correlation } \\
(r=0.93)\end{array}$ & immunoassay & 119 \\
\hline \multirow[t]{2}{*}{ Progesterone } & $\begin{array}{l}\text { correlation during late } \\
\text { pregnancy }\end{array}$ & saliva / serum & weak correlation & immunoassay & 120 \\
\hline & $\begin{array}{l}\text { correlation during the } \\
\text { menstrual cycle }\end{array}$ & saliva / plasma & $\begin{array}{l}\text { significant } \\
\text { correlation } \\
(r=0.58, \mathrm{p}=0.001)\end{array}$ & - & 121 \\
\hline \multirow[t]{2}{*}{ Estradiol } & $\begin{array}{l}\text { correlation studies in } \\
\text { postmenopausal } \\
\text { women }\end{array}$ & saliva / serum & $\begin{array}{l}\text { strong correlation } \\
\text { in users on } \\
\text { estrogen therapy } \\
(r=0.81)\end{array}$ & immunoassay & 122 \\
\hline & $\begin{array}{l}\text { monitoring follicular } \\
\text { stimulation }\end{array}$ & saliva / serum & $\begin{array}{l}\text { strong correlation } \\
(r=0.77)\end{array}$ & immunoassay & 123 \\
\hline \multirow[t]{2}{*}{ Estriol } & $\begin{array}{l}\text { correlation during } \\
\text { normal pregnancy }\end{array}$ & saliva / plasma & $\begin{array}{l}\text { strong correlation } \\
(r \geq 0.79)\end{array}$ & - & 124,125 \\
\hline & $\begin{array}{l}\text { correlation during third } \\
\text { trimester pregnancy }\end{array}$ & saliva / serum & $\begin{array}{l}\text { strong correlation } \\
(r=0.99)\end{array}$ & immunoassay & 126 \\
\hline Insulin & $\begin{array}{l}\text { normal and Type I } \\
\text { diabetic subjects }\end{array}$ & saliva / serum & $\begin{array}{l}\text { strong correlation } \\
(r=0.81)\end{array}$ & immunoassay & 127 \\
\hline \multirow[t]{2}{*}{ Melatonin } & correlation studies & saliva / serum & $\begin{array}{l}\text { strong correlation } \\
\left(r=0.95,{ }^{128}\right. \\
\left.r=0.81^{129}\right)\end{array}$ & immunoassay & 128,129 \\
\hline & circadian phase marker & saliva / plasma & $\begin{array}{l}\text { strong correlation } \\
\text { of time of onset } \\
(r=0.70)\end{array}$ & immunoassay & 130 \\
\hline \multicolumn{6}{|c|}{ Antibodies / Antigens } \\
\hline HIV antibody & HIV infection & saliva / serum & & immunoassay & 131,132 \\
\hline Immunoglobulin A (IgA) & $\begin{array}{l}\text { systemic sicca } \\
\text { syndrome and } \\
\text { rheumatoid arthritis }\end{array}$ & saliva / serum & $\begin{array}{l}\text { strong correlation } \\
(\mathrm{p}<0.001)\end{array}$ & immunoassay & 133 \\
\hline \multicolumn{6}{|c|}{ pH } \\
\hline pH & dental caries & saliva & - & - & 134 \\
\hline
\end{tabular}

* Prohibited doping substances that have been demonstrated to be detectable in saliva include amphetamine, metham-phetamine, norselegiline, ephedrine / norephedrine, ephedrine-d3, selegiline, pentetrazol, crotetamide, cropropamide, sibutramine, codeine / dihydrocodeine, modafinil, ISTD1, cocaina, cocaine-d3, BEG, BEG-d3, EME, EME-d3. ${ }^{106}$

\section{Detection methods:}

FID: flame ionization detector, GC: gas chromatography, GLC: gas-liquid chromatography, HPLC: high performance liquid chromatography, MS: mass spectrometry 


\section{Searches for biomarkers - what is needed and case histories}

Biomarkers may be classified into three different categories based on their origins and mechanisms of action: exposure, effect (response) and susceptibility. ${ }^{135}$ Any substances coming or arising from a source outside the organism or cell are referred to as 'exposure.' 'Effect' is a change in a biological system corresponding to impairment in the organism or cell, and is potentially related to diseases. The ability of the system to defend itself from toxic events is known as 'susceptibility.' For example, antioxidants reflect a type of susceptibility that responds to reactive oxidizing species and prevents oxidation processes that may otherwise damage important organisms or cells.

A compound, ion or metabolite is considered a good biomarker when it is representative of a specific condition of the target cell, disease or the health state of an individual. In other words, it should not be affected by other factors unrelated to the disease or condition under studies. For ease of detection, biomarkers should be present and measurable in samples which can be readily collected, and easily processed and stored. The concentrations of the biomarker in the normal control population should be well-examined and preferably invariant in the control group such that any small change can be detected with reliability. ${ }^{135}$

For diagnosis, there need to be reliable assays for the detection of the biomarkers of interest. Before any of the developed assays can be used in the real diagnosis of diseases, the followings have to be considered: the precision, accuracy, reproducibility, specificity, selectivity and sensitivity of the assays. The timescale of the measurements, costs and ease of use are also important factors. In the applications of the assays to real samples, collection methods, storage and preparation of the samples for analysis have to be optimized. The comparisons between different methods and the same methods performed by different laboratories have to be in agreement. The above mentioned parameters are summarized in Figure 3.

Figure 3 further outlines the important parameters that need to be considered in the search for new biomarkers. In the search for a new biomarker, the correlation between the disease/disorder and the presence or the concentrations of the biomarkers has to be directly investigated. For salivary biomarkers, the correlation with disease may be studied along with the correlation between saliva and blood plasma or serum levels. The statistical significance or the accuracy of the diagnosis of the biomarker in question is recommended to be assessed 
using i) sensitivity: the proportion of positive tests in the individuals in doubt of being diseased and ii) specificity: the proportion of negative tests in individuals without the disease. ${ }^{136}$ Notably, misdiagnosis as false positives is less likely to cause damage than false negatives. Individuals whose test results are positive will undergo further examination, while false negatives could lead to the disease not being detected and necessary treatments may be significantly delayed.

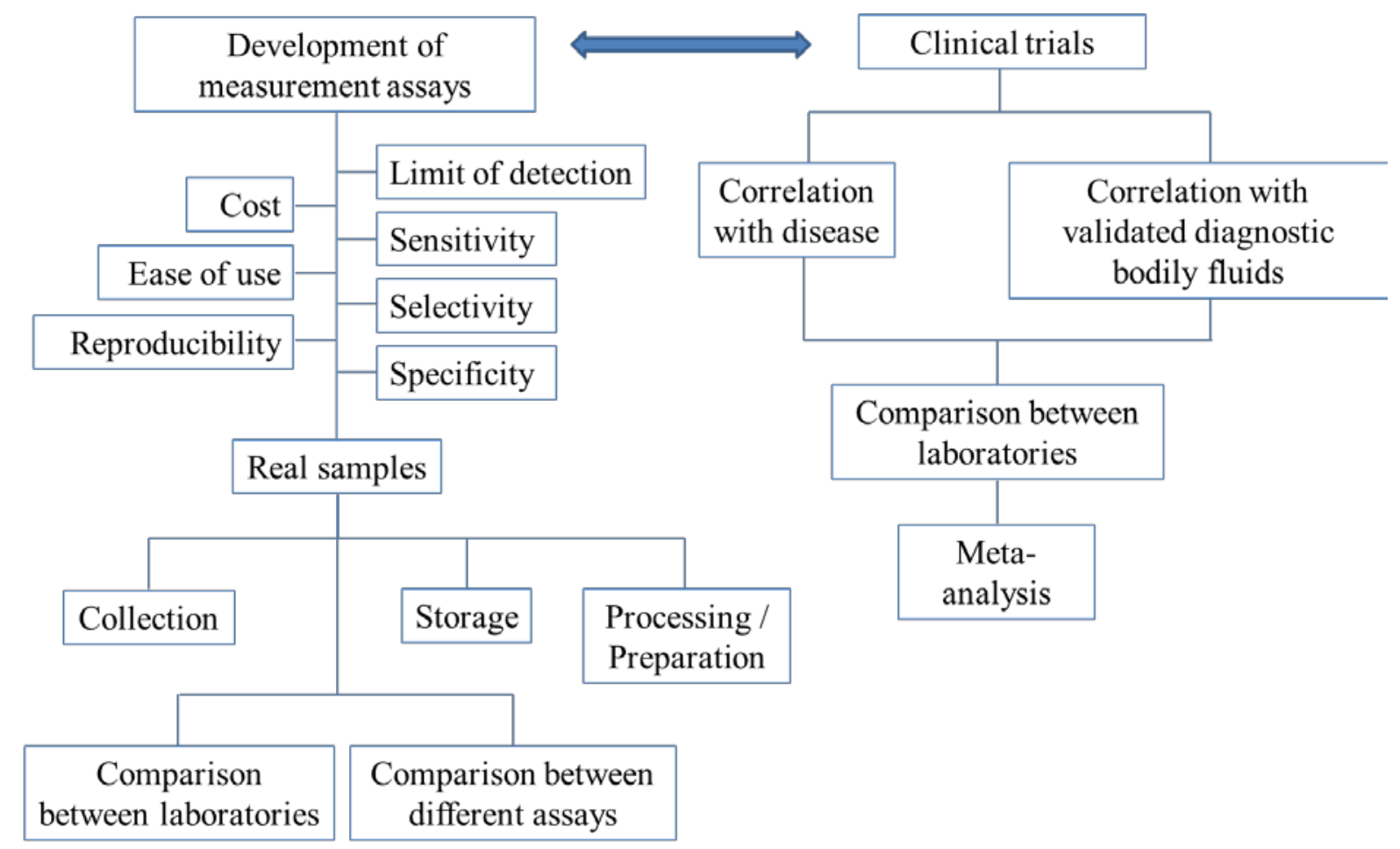

Figure 3: The outlines of factors/parameters needed to be considered in the development of new analytical assays for diagnostic applications and the procedure of the search for new biomarkers.

In the following, two successful case histories of saliva diagnostic tests are given as examples: cortisol and HIV antibody detection. Both have been developed into commercial products. In particular, the HIV saliva tests have been approved by the Food and Drug Administration (FDA) for home-use and for use at point-of-care sites. The importance of sample collection and storage is highlighted. Then the on-going research of glutathione as a biomarker for psychological disorders will be reviewed. 


\section{Cortisol}

Cortisol is a lipid-soluble steroid hormone. The saliva cortisol test has been used to assess the adrenal hormone function and psychological disorders such as depression. The cortisol level in saliva reflects the unbound level in blood plasma, of which is indicative of the activity of the hormone. ${ }^{107-111}$ Cortisol enters saliva by passive intracellular diffusion. Its level is independent of the saliva flow rate. ${ }^{137}$ Consequently, saliva may be used as a reliable diagnostic sample for cortisol monitoring. Cortisol can be detected via different techniques mainly chromatography and immunoassays based on luminescent, optical or electrical detection. ${ }^{138}$ In the commercial salivary cortisol test kits such as those by Salimetrics ${ }^{\circledR}$ and Oxford Biomedical Research ${ }^{\circledR}$, an enzyme-linked immunosorbent assay (ELISA) based on horseradish peroxidase is employed. There are different means as to how saliva can be collected and stored as described in Section 4. Cotton tools are known to alter the level of cortisol in saliva, while the synthetic Salivette ${ }^{\circledR}$ gives a reported recovery yield of $99.8 \% .{ }^{139}$ Hence, synthetic Salivettes are recommended for saliva collection for cortisol tests. Note also that cortisol levels change throughout the day (circadian rhythm). ${ }^{140}$ For development of any new biomarker, the time of sample collection, the method of collection and sample storage need to be optimized.

\section{$\underline{\text { HIV }}$}

The diagnosis to identify individuals infected by human immunodeficiency virus (HIV) is one of the examples where the advantage of understanding the aetiology is realized. Instead of directly detecting the virus, the HIV antibody which is also present in saliva can be detected. The diagnosis of HIV infection via saliva testing is a much safer method than blood analysis as the level of the antigen is very low and unlikely to be transmitted through saliva contact, reducing the risk of transmission during tests. ${ }^{141}$ Independent studies by Major et al. ${ }^{132}$ and Frerichs et al. ${ }^{131}$ reported a strong correlation of the appearance of HIV antibodies in saliva and serum samples. The results were consistent between laboratories. Major et al. ${ }^{132}$ reported complete concordance on the presence of HIV antibodies between matched saliva and serum samples, while Frerichs et al. ${ }^{131}$ found six disparate findings in over 1,000 samples demonstrating the high level of accuracy of the tests. The studies were performed under rigorous controls of the measurement methods with three different enzyme linked immunosorbent assays (ELISAs) following the WHO Confirmatory Strategy III in the work of Frerichs et al. ${ }^{131}$ The numbers of subjects studied were significantly large, such that, any 
risks of misdiagnosed have been carefully assessed. In addition to serum, plasma and saliva, the tests of antibody have been shown to be effective in whole blood, dried blood spots and urine. $^{142}$

\section{Glutathione}

Turning to the on-going research of glutathione as a potential biomarker for psychological disorders, the development of measurement assays and the possibility of saliva glutathione as a biomarker are discussed in this section.

The search for biomarkers is particularly important in psychiatry. For most psychological disorders, there is no reliable biomarker which can be used in the diagnosis, and patients may face life-long symptoms. Biomarkers which can be used to monitor the disorders are thus potentially desirable. Here, we focus on bipolar disorder (BD). Different from the case of HIV discussed above, the pathophysiology of BD is not clearly known. From the symptoms alone, it is also difficult to distinguish between BD and other disorders such as major depressive disorder. A hypothesis that $\mathrm{BD}$ is related to oxidative stress has been proposed. ${ }^{143}$ As a major antioxidant, glutathione becomes one of the potential biomarkers for BD and an increasing number of researches have focussed on this compound.

A number of assays have been developed for the selective and specific measurements of reduced (GSH) and oxidized (GSSG) glutathione. The most commonly used method for glutathione measurement to date is the Tietze enzymatic assay which measures the concentration of total glutathione (GSH + GSSG). The Tietze assay is based on the use of an enzyme glutathione reductase (GR) for the high selectivity of the assay, and the reaction between Ellman's reagent (DTNB) and GSH to produce a yellow product which can be detected using UV-visible spectrophotometry. The assay is summarized in Figure $4 .{ }^{144}$ 


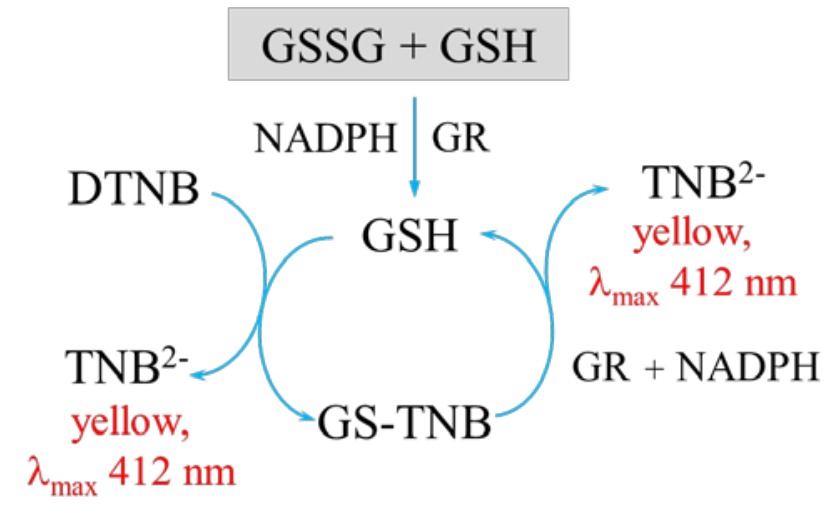

Figure 4: The Tietze enzymatic assay for the determination of total glutathione concentrations. GSH: reduced glutathione, GSSG: oxidized glutathione, GR: glutathione reductase, NADPH: nicotinamide adenine dinucleotide phosphate, DTNB: 5,5'-dithiobis(2-nitrobenzoic acid), TNB $^{2-}$ : 5-thio-2-nitrobenzoate.

The enzyme reduces GSSG to GSH at the beginning of the assay. Therefore to measure the concentration of either GSH or GSSG, a further step of using a masking reagent is required. Tietze $^{144}$ proposed the use of $N$-ethylmaleimide (NEM) as a masking agent. NEM completes the reaction with GSH almost instantaneously, but any excess NEM has to be removed from the system as it will inhibit the activity of the enzyme (glutathione reductase) used in the measurement assay, and further the compound is highly toxic. NEM removal can require a lot of efforts and take a long time. ${ }^{144,145}$ The work of Griffith ${ }^{146}$ suggests the alternative use of 2vinylpyridine (2VP) as a masking reagent. 2VP is less toxic than NEM, and does not need to be removed from the system. However, 2VP takes ca. one hour for the reaction to go to completion. This one-hour period can significantly alter the result as will be further discussed below.

Shaik and Mehvar ${ }^{147}$ suggested the use of 1-methyl-4-vinyl-pyridinium trifluoromethane sulfonate as a masking reagent, while some of the present articles ${ }^{148}$ recommend benzoquinone as an alternative. Both reported the complete reactions almost instantly ( $<2$ min). Ngamchuea et al. ${ }^{148}$ further suggest a quick route to remove the masking agents remaining in the samples simply by adding a non-glutathione thiol. The methods have been demonstrated to have high sensitivity and selectivity, and have been successfully applied to real samples such as whole blood, blood plasma and saliva. Other means of measuring glutathione include chromatographic methods (HPLC, GC), ${ }^{149,} 150$ capillary electrophoresis, ${ }^{151,} 152$ nanoparticle-based colorimetric tests, ${ }^{153}$ and chemiluminescence. ${ }^{154}$ Electrochemical techniques have also been reported. ${ }^{155-158}$ It can be said that at this stage, the 
assays for glutathione measurements are well-developed. The next step requires progress in clinical studies.

Rosa et al. ${ }^{159}$ investigated the correlations between total (GSH + GSSG), reduced (GSH) and oxidized (GSSG) glutathione in blood plasma from 50 bipolar and 50 control subjects, using the Tietze assay and 2VP masking agent. Rosa et al. ${ }^{159}$ observed lower both total and GSH levels in BD patients than in controls $(\mathrm{p} \leq 0.05)$. Other factors such as smoking showed no sign of escalating the level of oxidative stress in BD patients, ${ }^{159}$ although some studies reported the effects of smoking on glutathione levels in healthy control populations. ${ }^{160}$ Raffa et al. ${ }^{143}$ and Gawryluk et al. ${ }^{161}$ studied the correlations between glutathione and BD in red blood cells (40 controls and $30 \mathrm{BD}$; Tietze assay and NEM) and post-mortem prefrontal cortex (12 controls and $14 \mathrm{BD}$; Tietze assay and 2VP) respectively. Both found the levels of total and reduced glutathione to be lower in BD patients.

Tuncel et al. ${ }^{162}$ also studied the plasma total glutathione levels in $18 \mathrm{BD}$ and 18 control subjects using the Tietze assay. They observed the plasma total glutathione levels are higher in $\mathrm{BD}$ patients than the control group, but the results are not statistically significant ( $\mathrm{p}=$ 0.51). Lagopoulos et al. (51 controls and 53 BD; ${ }^{1} \mathrm{H}-\mathrm{MRS}$ ) ${ }^{163}$ and Godlewska et al. (11 controls and $13 \mathrm{BD}$; $\left.{ }^{1} \mathrm{H}-\mathrm{MRS}\right){ }^{164}$ found no significant difference in GSH levels in the cortex between $\mathrm{BD}$ patients and the control groups.

There are many possible explanations for the discrepancy of the results discussed above. The sample sizes in BD studies, in the range of 11-50 samples, may be relatively small, giving rise to high possibilities that the population is not representative of the inhomogeneous population. Moreover, there are not necessarily correlations between glutathione levels in different biological fluids/compartments. ${ }^{47}$ For example, Kand'ar et al. ${ }^{165}$ reported no correlation between the levels of reduced (GSH) and oxidized (GSSG) glutathione in whole blood and blood plasma collected from healthy participants. Similarly, there are reports suggesting that there is no correlation between the concentrations of total glutathione (GSH + GSSG) in blood plasma as compared with epithelial lining fluid ${ }^{166}$ and seminal plasma. ${ }^{167}$

There are also different types of BD (e.g. types I and II). The levels of glutathione may be different at the different stages of the disease, or during depression and mania. The effects of treatment, medication and other influences such as smoking and alcohol consumption may have to be considered. For plasma samples, different preparation procedures have been shown to significantly alter the measured glutathione concentrations. ${ }^{168}$ In plasma samples, 
glutathione concentrations also change at rapid rates (half-life of ca. $30 \mathrm{~min}$ ) due to the activity of $\gamma$-glutamyltransferase enzyme and metal-catalyzed oxidation of GSH to GSSG. ${ }^{148}$ On the other hand, salivary glutathione displays significantly greater stability. At the temperature of $-20^{\circ} \mathrm{C}$, saliva GSH has been demonstrated to be stable for 11 days, ${ }^{169}$ while at room temperature, saliva GSH is stable for at least 90 min. ${ }^{148}$ The stability of saliva GSH offers a great advantage in diagnostic/clinical applications in addition to the non-invasive nature of saliva collection.

\section{Potential problems of the measurements of biomarkers in saliva}

Saliva is a viscous fluid due to the presence of mucopolysaccharides and mucoproteins. The difficulty in measuring precise volumes of viscous saliva samples can decrease the accuracy of analytical measurements. Importantly, most potential biomarkers are present in saliva at low concentrations. Any error in volume may give rise to large errors in the concentrations measured. Due to the low concentrations, assays with high sensitivity and low limit of detection are required, in addition to high selectivity and specificity. The components of saliva may depend on the area in the oral cavity in which the sample is collected as well as the collection methods (unstimulated vs. stimulated). If stimulation is used, the effects of the collection tools (e.g. cotton pads, polyester swabs, paraffin wax) and/or the chemicals (e.g. citric acid) have to be carefully assessed, as previously discussed in Section 4 and in the case of cortisol. Oral diseases such as gingivitis, the change in $\mathrm{pH}$ and other potential interferences such as smoking, fasting and hydration level can also influence the levels of the biomarkers of interest. ${ }^{170}$

There are relatively large variations in metabolite concentrations between different individuals. Calcium and phosphate concentrations in unstimulated whole saliva vary significantly between individuals (ca. 4-fold and 6-fold ranges of calcium and phosphate concentrations respectively) although the samples are collected at the same time of the day and have similar $\mathrm{pH}$ and buffer capacity. ${ }^{171}$ The marked inter-individual variation is likely because many salivary components play multifunctional roles and in some cases, have overlapping functions. ${ }^{172}$ For example, glutathione, ascorbic acid and uric acid are all antioxidants. Amylases, cystatins, histatins, mucins and peroxidases are all involved in antibacterial activity in the oral cavity. Diurnal fluctuation, seasons (temperature) and other intraindividual inconsistency may also have to be considered. Accordingly, single salivary analysis could be unreliable. Multiple saliva samples and follow-up tests are desirable. 


\section{$7 \quad$ Electroanalysis in saliva}

Electrochemical measurements provide simple, rapid and inexpensive methods for the detection of analytes and often exhibit high sensitivity over linear ranges. A variety of electrochemical techniques are available for the detection of analytes including potentiometric, voltammetric and amperometric measurements. Techniques which minimize the contribution of capacitative currents such as square-wave voltammetry and differential pulse voltammetry may also be used to improve the sensitivity and limit of detection of the measurements. Table 4 provides examples of the reported electrochemical methods in the detection of some salivary biomarkers listed in Table 3. Note that methods that involve the use of biologically selective materials are not included. For methods that use the same technique, only some of the methods that reported lower limits of detection or methods that have been validated in biological samples are presented in Table 4.

Despite the many advantages, electrochemical assays are relatively less common in diagnostic and clinical uses. It can also be seen from Table 4 that in many cases, the developed assays have not been tested with real biological samples. The lack of such validations may be one of the reasons the applications of electroanalysis in diagnostic fields are relatively limited. The difficulty of electrochemical measurement in bio-samples lies in the selectivity and specificity of the methods as there are many potential interferences in real samples.

To improve the selectivity and specificity of the electrochemical assays, biologically selective substances such as enzymes, antibodies or antigens may be used. Using the diagnosis of cancers as an example, the cancer antibodies can be immobilized on an electrode surface. The cancer antigens such as $\alpha$-fetoprotein in the samples can then be detected by the antibodyantigen recognition. ${ }^{173}$ In biosensors and immunosensors, it is important to consider the conductivity of the electrode after modification, the stability of the antibody receptors, and that they retain the bio-activities. The major disadvantages of such sensors could be the effort required in the production of enzymes, antigens or antibodies, the fabrication of the modified electrodes and questions over the reusability of the electrodes.

The selectivity of electrochemical assays can also be improved without the need for bioselective molecules. Compounds which carry the same functional groups or have similar structures are likely to undergo electrochemical reactions at similar potentials and hence be 
indistinguishable in the resulting electrochemical responses. They may however have different reaction kinetics. The use of different scan rates in voltammetric measurements may allow the separation of the peaks and elimination of interferences. For example, dopamine, ascorbic acid and uric acid, all of which are important metabolites in biological fluids. The measurement of the concentrations of individual species poses difficulties as they have similar oxidation potentials. However, it has been shown that the detection of dopamine in the presence of ascorbic acid or uric acid in the presence of ascorbic acid can be achieved by fast scan voltammetry at bare electrodes because of the differences in their electrochemical kinetics. ${ }^{174}$

Alternatively, the use of small organic or inorganic molecules as redox mediators may allow otherwise electrochemically inert species to be detected. Different reaction mechanisms or rates of reactions with the mediators offer the simultaneous detection of different species. For example, the thiol-containing amino acids do not undergo oxidation nor reduction in the potential window that is easily achieved in aqueous media. It was shown that $o$-benzoquinone undergoes fast reaction with thiols via two possible mechanisms: 1,4-Michael addition and electrocatalytic reaction, with the former being the main pathway. ${ }^{175} O$-benzoquinone exhibits a clear electrochemical response in the suitable potential window, and hence can be used as a redox mediator in the detection of thiol species. The reactions between o-benzoquinone and thiols form adducts as a result of the 1,4-addition reaction. Because the products are different for the different thiols, they display the voltammetric peaks at distinct potentials and thus allow the simultaneous detection of the different anti-oxidants such as cysteine, homocysteine, glutathione and ascorbic acid by simple voltammetry measurement without the need for deoxygenation or further sample preparation. ${ }^{175}$ In the case that the resulting adducts give rise to similar reduction potentials, the utilization of different scan rates can be applied to further increase the selectivity.

In addition to the change in scan rates, the modification of electrodes by conducting porous layers can be employed to improve the selectivity of the electrochemical sensors. The formation of thin porous layers on the electrode surface changes the mass transport regimes of the redox-active species to the electrode from planar (linear) diffusion to 'thin layer' behaviour. As a result, the voltammetric peaks are shifted and compounds which originally give rise to voltammetric peaks at the same or similar potentials may now show separated peaks, provided that the values of electrochemical parameters such as the formal potential $\left(E_{\mathrm{f}}\right)$, the standard electrochemical rate constant $\left(k_{0}\right)$ and transfer coefficient $(\alpha)$ are different. 
For example, Henstridge et al. ${ }^{176}$ modified the surface of glassy carbon electrodes with multiwalled carbon nanotubes. The modified electrodes were able to detect dopamine in the presence of interferences such as uric acid, serotonin and ascorbic acid, which would otherwise display voltammetric peaks at similar potentials at bare glassy carbon electrodes.

For systems that undergo inner-sphere electron transfers or processes that involve adsorption of the redox-active species to the electrode surface, the change in the electrode materials or morphology can offer improvement of the selectivity. For example, carbon electrodes with different structures (e.g. glassy carbon, edge/basal plane pyrolytic graphite, carbon fiber and carbon nanomaterials) have been shown to yield different electron transfer kinetics. ${ }^{177,} 178$ Ion-selective electrodes have also been developed for detection of specific ions by converting the activity of the ion into a potential such as allows the detection of calcium and potassium. ${ }^{179,} 180$ Nanoparticles and nanomaterials in sensors have been demonstrated to display enhanced sensitivity as well as increase the selectivity of the electrochemical detection. ${ }^{181}$ The development of various forms of portable electrode platforms such as screen-printed electrodes, ${ }^{182-184}$ microwire electrodes, ${ }^{158,} 185$ as well as stretchable and wearable electrodes ${ }^{186}$ also facilitates the uses of electrochemistry in bio-sensing. 
Table 4 Examples of methods of electroanalytical detection available for possible salivary biomarkers (listed in Table 3)

\begin{tabular}{|c|c|c|c|c|c|c|}
\hline Biomarkers & Methods & Electrodes & Linear range & LOD & Medium & Ref \\
\hline \multicolumn{7}{|c|}{ Chemicals } \\
\hline Calcium & ISE & calcium-specific electrode & $2.2-8 \mathrm{mg} / 100 \mathrm{~mL}$ & - & aqueous, serum & 179 \\
\hline Potassium & ISE & $\begin{array}{l}\text { potassium electrode with } \\
\text { polymer membrane }\end{array}$ & $115 \mathrm{mM}-180 \mathrm{mM}^{*}$ & - & $\begin{array}{l}\text { whole blood, } \\
\text { serum }\end{array}$ & 180 \\
\hline Phosphate & AMP, CV & $\begin{array}{l}\text { molybdate anions in } \\
\text { chitosan/GC }\end{array}$ & $19 \mu \mathrm{M}-95 \mu \mathrm{M}$ & & $\begin{array}{l}\text { deaerated } \\
\text { Tris buffer }(\mathrm{pH} \\
7.0)\end{array}$ & 187 \\
\hline \multirow[t]{2}{*}{ Cotinine } & MPA & BDD & $0.5 \mu \mathrm{M}-100 \mu \mathrm{M}$ & $0.06 \mu \mathrm{M}$ & $\begin{array}{l}\text { PBS (pH 7.0), } \\
\text { saliva }\end{array}$ & 188 \\
\hline & SWV & anti-cotinine antibody/C-SPE & $1-100 \mathrm{ng} \mathrm{mL}^{-1}$ & $\begin{array}{l}1.0 \mathrm{ng} \\
\mathrm{mL}^{-1}\end{array}$ & serum & 189 \\
\hline \multirow[t]{6}{*}{ Nicotine } & AMP, CV & $\begin{array}{l}\text { MWCNT/alumina-coated } \\
\text { silica nanocomposite }\end{array}$ & - & $1.42 \mu \mathrm{M}$ & PBS (pH 8) & 190 \\
\hline & AMP & $\mathrm{TiO}_{2} / \mathrm{GC}$ & $0 \mu \mathrm{M}-5000 \mu \mathrm{M}$ & $4.9 \mu \mathrm{M}$ & PBS (pH 7.4) & 191 \\
\hline & $\mathrm{CV}$ & MWCNT/BPPG & up to $1 \mathrm{mM}$ & $1.5 \mu \mathrm{M}$ & $\mathrm{BR}(\mathrm{pH} 8)$ & 192 \\
\hline & $\mathrm{CV}$ & $\mathrm{CNT} / \mathrm{SPE}$ & $10 \mu \mathrm{M}-1000 \mu \mathrm{M}$ & $2 \mu \mathrm{M}$ & $\begin{array}{l}\text { buffer ( } \mathrm{pH} 7) \text {, } \\
\text { artificial saliva }\end{array}$ & 193 \\
\hline & DPV & BDD & $0.5 \mu \mathrm{M}-200 \mu \mathrm{M}$ & $0.3 \mu \mathrm{M}$ & BR (pH 8) & 194 \\
\hline & EIS & polydopamine imprinted film & $1 \mu \mathrm{M}-25 \mu \mathrm{M}$ & $0.5 \mu \mathrm{M}$ & $\begin{array}{l}\text { PBS (pH 7.4), } \\
\text { serum }\end{array}$ & 195 \\
\hline Nitrate $\left(\mathrm{NO}_{3}{ }^{-}\right)$ & LSV & $\begin{array}{l}\mathrm{Cu} \text { plated/BDD } \\
\text { microelectrode array }\end{array}$ & $1.2 \mu \mathrm{M}-124 \mu \mathrm{M}$ & $0.76 \mu \mathrm{M}$ & $\begin{array}{l}0.1 \mathrm{M} \mathrm{Na}_{2} \mathrm{SO}_{4} \\
(\mathrm{pH} \mathrm{3})\end{array}$ & 196 \\
\hline \multirow{5}{*}{ Nitrite $\left(\mathrm{NO}_{2}^{-}\right)$} & \multirow[t]{2}{*}{ AMP } & cellulose acetate membrane/Pt & $1 \mu \mathrm{M}-100 \mu \mathrm{M}$ & $0.5 \mu \mathrm{M}$ & \multirow{2}{*}{$\begin{array}{l}\text { acetate buffer } \\
(\mathrm{pH} 4.0)\end{array}$} & \multirow[t]{2}{*}{197} \\
\hline & & $\begin{array}{l}\text { poly(1,8-diaminonaphthalene) } \\
\text { film/Pt }\end{array}$ & $0.5 \mu \mathrm{M}-100 \mu \mathrm{M}$ & $0.1 \mu \mathrm{M}$ & & \\
\hline & \multirow{2}{*}{$\begin{array}{l}\text { AMP, } \\
\text { DPV }\end{array}$} & carbon black paste electrode & $0.01 \mu \mathrm{M}-4 \mu \mathrm{M}$ & $0.005 \mu \mathrm{M}$ & \multirow{2}{*}{$\begin{array}{l}\text { acetate buffer } \\
\text { (pH 4.6) }\end{array}$} & \multirow[t]{2}{*}{198} \\
\hline & & carbon black SPE & $0.1 \mu \mathrm{M}-8.8 \mu \mathrm{M}$ & $0.097 \mu \mathrm{M}$ & & \\
\hline & $\begin{array}{l}\text { DPV, } \\
\text { LSV }\end{array}$ & GC & $4 \mathrm{mM}-80 \mathrm{mM}$ & $6 \mu \mathrm{M}$ & saliva, urine & 199 \\
\hline \multirow[t]{5}{*}{ Caffeine } & $\mathrm{CV}$ & nafion/GC & up to $7.0 \mathrm{mM}$ & $0.04 \mu \mathrm{M}$ & PBS (pH 7.0) & 200 \\
\hline & CV, SWV & pseudo CP & $1 \mu \mathrm{M}-1 \mathrm{mM}$ & $0.348 \mu \mathrm{M}$ & PBS (pH 7.0) & 201 \\
\hline & DPV & $\begin{array}{l}\text { molecularly imprinted } \\
\text { polymer }\end{array}$ & $0.5 \mathrm{nM}-0.16 \mu \mathrm{M}$ & $0.9 \mathrm{pM}$ & PBS (pH 6.5) & 202 \\
\hline & DPV & SWCNT/CC & $0.25 \mu \mathrm{M}-10 \mathrm{mM}$ & $0.12 \mu \mathrm{M}$ & $\begin{array}{l}0.01 \mathrm{M} \mathrm{H}_{2} \mathrm{SO}_{4} \\
(\mathrm{pH} 1.7)\end{array}$ & 203 \\
\hline & SWV & EPPG & $0.02 \mu \mathrm{M}-100 \mu \mathrm{M}$ & $0.008 \mu \mathrm{M}$ & $\begin{array}{l}\text { PBS (pH 7.2), } \\
\text { urine }\end{array}$ & 204 \\
\hline \multirow[t]{2}{*}{ Thiocyanate (SCN$\left.{ }^{-}\right)$} & CV, DPV & Ag-MWCNT/GC & $\begin{array}{l}2.5 \mathrm{nM}-50 \mathrm{nM} \\
50 \mathrm{nM}-1.0 \mu \mathrm{M}\end{array}$ & $1.0 \mathrm{nM}$ & $\begin{array}{l}\text { PBS (pH 6.0), } \\
\text { saliva, urine }\end{array}$ & 205 \\
\hline & CV, AMP & Ag@Cu nanorods/GC & $1 \mathrm{mM}-10 \mathrm{mM}$ & $10 \mathrm{nM}$ & PBS (pH 6.0) & 206 \\
\hline \multicolumn{7}{|c|}{ Anti-oxidants } \\
\hline \multirow[t]{9}{*}{$\begin{array}{l}\text { Glutathione } \\
\text { (GSH)** }\end{array}$} & $\mathrm{CV}$ & copper hydroxide/CILE & $\begin{array}{l}1 \mu \mathrm{M}-50 \mu \mathrm{M}, \\
0.1 \mathrm{mM}-1.8 \mathrm{mM}\end{array}$ & $30 \mathrm{nM}$ & PBS (pH 7.0) & 207 \\
\hline & CV, AMP & ordered mesoporous carbon & $0 \mathrm{mM}-2.5 \mathrm{mM}^{*}$ & $0.09 \mu \mathrm{M}$ & PBS (pH 7.16) & 208 \\
\hline & CV, AMP & carbon microfiber & $5 \mu \mathrm{M}-65 \mu \mathrm{M}^{*}$ & $0.5 \mu \mathrm{M}$ & PBS (pH 7.5) & 158 \\
\hline & $\mathrm{CV}$ & $\begin{array}{l}\text { poly(caffeic acid) nanocarbon } \\
\text { composite/GC }\end{array}$ & $0.5 \mu \mathrm{M}-5.0 \mathrm{mM}$ & $0.5 \mu \mathrm{M}$ & PBS (pH 7.0) & 209 \\
\hline & $\mathrm{CV}$ & GC & $6 \mu \mathrm{M}-59 \mu \mathrm{M}$ & $1 \mu \mathrm{M}$ & $\begin{array}{l}\text { tissue media }(\mathrm{pH} \\
7)\end{array}$ & 210 \\
\hline & $\mathrm{CV}$ & Prussian blue/SPE & $2 \mu \mathrm{M}-0.5 \mathrm{mM}$ & $2.0 \mu \mathrm{M}$ & blood (pH 7.4) & 211 \\
\hline & $\mathrm{CV}$ & nanocarbon paste & $2 \mu \mathrm{M}-120 \mu \mathrm{M}^{*}$ & $2.0 \mu \mathrm{M}$ & PBS (pH 7.5) & 212 \\
\hline & $\mathrm{CV}$ & caffeic acid/GC & $3.0 \mu \mathrm{M}-5.0 \mathrm{mM}$ & $2.2 \mu \mathrm{M}$ & PBS (pH 7.0) & 213 \\
\hline & CV, SWV & CNT-SPE & $10 \mu \mathrm{M}-60 \mu \mathrm{M}^{*}$ & $3.0 \mu \mathrm{M}$ & $\begin{array}{l}\text { PBS ( } \mathrm{pH} 7.0) \\
\text { saliva }\end{array}$ & 156 \\
\hline $\begin{array}{l}\text { Glutathione disulfide } \\
\text { (GSSG) }\end{array}$ & $\mathrm{CV}$ & copper hydroxide/CIL & $0.4 \mu \mathrm{M}-120 \mu \mathrm{M}$ & $15 \mathrm{nM}$ & PBS (pH 7.0) & 207 \\
\hline \multirow[t]{4}{*}{ Ascorbic acid } & CV, DPV & graphene-Pt/GC & $0.15 \mu \mathrm{M}-34 \mu \mathrm{M}$ & $0.15 \mu \mathrm{M}$ & PBS (pH 7.0) & 214 \\
\hline & DPV & nitrogen doped graphene & $5.0 \mu \mathrm{M}-1.3 \mathrm{mM}$ & $2.2 \mu \mathrm{M}$ & PBS (pH 6.0) & 215 \\
\hline & CV, LSV & SWCNH/GC & $30 \mu \mathrm{M}-400 \mu \mathrm{M}$ & $5 \mu \mathrm{M}$ & PBS (pH 7.0) & 216 \\
\hline & $\mathrm{CV}, \mathrm{DPV}$ & poly(acid chrome blue K)/GC & $50.0-1000.0 \mu \mathrm{M}$ & $10.0 \mu \mathrm{M}$ & $\begin{array}{l}\text { PBS ( } \mathrm{pH} 4.0) \text {, } \\
\text { urine }\end{array}$ & 217 \\
\hline
\end{tabular}




\begin{tabular}{|c|c|c|c|c|c|c|}
\hline Biomarkers & Methods & Electrodes & Linear range & LOD & Medium & Ref \\
\hline \multirow[t]{8}{*}{ Uric acid } & CV, DPV & graphene-Pt/GCE & $0.05 \mu \mathrm{M}-12 \mu \mathrm{M}$ & $0.05 \mu \mathrm{M}$ & PBS (pH 7.0) & 214 \\
\hline & CE/AMP & $\begin{array}{l}\text { poly(dimethylsiloxane) } \\
\text { (PDMS)/glass microchip }\end{array}$ & $15 \mu \mathrm{M}-110 \mu \mathrm{M}$ & $1 \mu \mathrm{M}$ & $\begin{array}{l}\text { MES (pH 5.5), } \\
\text { urine }\end{array}$ & 218 \\
\hline & DPV & nitrogen doped graphene & $0.1 \mu \mathrm{M}-20 \mu \mathrm{M}$ & $0.45 \mathrm{nM}$ & PBS (pH 6.0) & 215 \\
\hline & SWV & clay colloids/GC & $\begin{array}{l}0.5 \mu \mathrm{M}-10 \mu \mathrm{M} \\
10 \mu \mathrm{M}-100 \mu \mathrm{M}\end{array}$ & $0.2 \mu \mathrm{M}$ & $\begin{array}{l}\text { citrate buffer }(\mathrm{pH} \\
1.0)\end{array}$ & 219 \\
\hline & DPV & CIL & $2.0 \mu \mathrm{M}-0.2 \mathrm{mM}$ & $1.0 \mu \mathrm{M}$ & $\begin{array}{l}\text { PBS (pH 6.8), } \\
\text { urine }\end{array}$ & 220 \\
\hline & CV, DPV & poly(acid chrome blue K)/GC & $1.0 \mu \mathrm{M}-120 \mu \mathrm{M}$ & $0.5 \mu \mathrm{M}$ & $\begin{array}{l}\text { PBS (pH 4.0), } \\
\text { urine }\end{array}$ & 217 \\
\hline & CV, LSV & SWCNH/GC & $0.06 \mu \mathrm{M}-10 \mu \mathrm{M}$ & $20 \mathrm{nM}$ & PBS (pH 7.0) & 216 \\
\hline & SWV & $\begin{array}{l}\text { electrochemically activated } \\
\text { GC }\end{array}$ & $0.04 \mu \mathrm{M}-2.0 \mu \mathrm{M}$ & $9 \mathrm{nM}$ & $\begin{array}{l}0.5 \mathrm{M} \mathrm{H}_{2} \mathrm{SO}_{4} \text {, } \\
\text { urine }\end{array}$ & 221 \\
\hline \multicolumn{7}{|c|}{ Therapeutic drugs } \\
\hline \multirow[t]{5}{*}{ Theophylline } & $\mathrm{CV}$ & MWCNT/GC & $0.3 \mu \mathrm{M}-10.0 \mu \mathrm{M}$ & $50 \mathrm{nM}$ & PBS (pH 5.8) & 222 \\
\hline & DPV & graphene/Nafion/GC & $\begin{array}{l}10 \mathrm{nM}-1.0 \mu \mathrm{M} \\
2.0 \mu \mathrm{M}-30 \mu \mathrm{M}\end{array}$ & $6.0 \mathrm{nM}$ & $0.1 \mathrm{M} \mathrm{H}_{2} \mathrm{SO}_{4}$ & 223 \\
\hline & DPV & cobalt phthalocyanine NP/CP & $0.4 \mu \mathrm{M}-0.1 \mathrm{mM}$ & $0.14 \mu \mathrm{M}$ & PBS (pH 7.4) & 224 \\
\hline & DPV & $\begin{array}{l}\text { urchin-like CdSe } \\
\text { microparticles/GC }\end{array}$ & $\begin{array}{l}1.0 \mu \mathrm{M}-40 \mu \mathrm{M} \\
40 \mu \mathrm{M}-700 \mu \mathrm{M}\end{array}$ & $0.4 \mu \mathrm{M}$ & PBS (pH 6.0) & 225 \\
\hline & SWV & $\begin{array}{l}\text { Nafion/lead-ruthenium oxide } \\
\text { pyrochlore }\end{array}$ & up to $100 \mu \mathrm{M}$ & $0.1 \mu \mathrm{M}$ & PBS (pH 3) & 226 \\
\hline \multirow{8}{*}{$\begin{array}{l}\text { Acetaminophen } \\
\text { (paracetamol) }\end{array}$} & $\mathrm{CV}$ & Nafion/TiO ${ }_{2}$-graphene/GC & \multirow{2}{*}{$\begin{array}{l}1 \mu \mathrm{M}-100 \mu \mathrm{M} \\
5 \mathrm{nM}-0.5 \mu \mathrm{M}, \\
0.5 \mu \mathrm{M}-80.0 \mu \mathrm{M}\end{array}$} & $0.21 \mu \mathrm{M}$ & PBS (pH 7.0) & 227 \\
\hline & DPV & Pd/graphite oxide/GC & & $2.2 \mathrm{nM}$ & PBS (pH 6.8) & 228 \\
\hline & DPV & $\mathrm{BiO} /$ graphite SPE & $0.5 \mu \mathrm{M}-1,250 \mu \mathrm{M}$ & $30 \mathrm{nM}$ & $\begin{array}{l}\text { BR buffer ( } \mathrm{pH} \\
2.0) \text {, saliva }\end{array}$ & 229 \\
\hline & DPV & SWCNT-graphene/GC & $0.05 \mu \mathrm{M}-65 \mu \mathrm{M}$ & $38 \mathrm{nM}$ & $\begin{array}{l}\text { PBS (pH 7.0), } \\
\text { serum }\end{array}$ & 230 \\
\hline & DPV & functionalized MWCNT & $0.45 \mu \mathrm{M}-90.0 \mu \mathrm{M}$ & $0.35 \mu \mathrm{M}$ & $\begin{array}{l}\text { PBS (pH 7.0), } \\
\text { saliva }\end{array}$ & 231 \\
\hline & SWV & CoNP/MWCNT & $5.2 \mathrm{nM}-0.45 \mu \mathrm{M}$ & $1.0 \mathrm{nM}$ & PBS (pH 7.0) & 232 \\
\hline & SWV & MWCNT/BPPG & $\begin{array}{l}0.01 \mu \mathrm{M}-2 \mu \mathrm{M} \\
2 \mu \mathrm{M}-20 \mu \mathrm{M}\end{array}$ & $10 \mathrm{nM}$ & PBS (pH 7.5) & 233 \\
\hline & SWV & graphene/GC & $0.1 \mu \mathrm{M}-20 \mu \mathrm{M}$ & $32 \mathrm{nM}$ & $\begin{array}{l}\mathrm{NH}_{3} \cdot \mathrm{H}_{2} \mathrm{O}-\mathrm{NH}_{4} \mathrm{Cl} \\
(\mathrm{pH} 9.3)\end{array}$ & 234 \\
\hline \multicolumn{7}{|c|}{ pH } \\
\hline \multirow[t]{4}{*}{ pH } & $\mathrm{CV}$ & carbon fibre microelectrode & $\begin{array}{l}\text { pH 2.5-8 } \\
\text { (buffer), } \\
\text { pH 4-8.5 } \\
\text { (artificial } \\
\text { saliva) }\end{array}$ & $\begin{array}{l}\text { Sensitivity: } \\
-61 \mathrm{mV} / \mathrm{pH} \\
\text { (buffer), } \\
-73 \mathrm{mV} / \mathrm{pH} \\
\text { (artificial saliva) }\end{array}$ & $\begin{array}{l}\text { buffer, artificial } \\
\text { saliva, saliva }\end{array}$ & 235 \\
\hline & EIS & Iridium oxide & $\mathrm{pH} 4-8$ & $\begin{array}{l}\text { Sensitivity: } \\
-47 \mathrm{mV} / \mathrm{pH} \\
\text { (artificial saliva) }\end{array}$ & artificial saliva & 236 \\
\hline & ISE & $\begin{array}{l}\text { Poly(3-octylthiophene-2,5- } \\
\text { diyl)regiorandum/SPCE }\end{array}$ & $\mathrm{pH} 4-8$ & $\begin{array}{l}\text { Sensitivity: } \\
-53.4 \mathrm{mV} / \mathrm{pH} \\
\text { (buffer) }\end{array}$ & buffer, saliva & 237 \\
\hline & ISE & $\begin{array}{l}\text { Poly(terthiophene benzoic } \\
\text { acid)/AuZnOx/ SPCE }\end{array}$ & $\mathrm{pH} \mathrm{2-13}$ & $\begin{array}{l}\text { Sensitivity: } \\
59.2 \pm 0.5 \\
\mathrm{mV} / \mathrm{pH} \text { (buffer) }\end{array}$ & $\begin{array}{l}\text { buffer, saliva, } \\
\text { urine }\end{array}$ & 238 \\
\hline
\end{tabular}

The methods highlighted in grey and blue have been validated in artificial saliva and real saliva respectively.

\section{Methods}

AMP: amperometry, CA: chronoamperometry, CE: capillary electrophoresis, CV: cyclic voltammetry, DPV: differential pulse voltammetry, EIS: electrochemical impedance spectroscopy, ISE: ion-selective electrode, LSV: linear sweep voltammetry, MPA: multiple-pulse amperometry, SWV: square wave voltammetry

\section{Electrodes}

BDD: boron-doped diamond, BPPG: basal plane pyrolytic graphite, CC: carbon ceramic, CIL: carbon ionic liquid, CNF: carbon nanofiber, CP: carbon paste, EPPG: edge plane pyrolytic graphite, GC: glassy carbon electrode, MWCNT: multi-walled carbon nanotube, NP: nanoparticle, SPE: screen-printed electrodes, SWCNT: single-walled carbon nanotube, SWCNH: single-walled carbon nanohorn

* Not stated in the text - values are taken from calibration curves present in the papers 


\section{Conclusions}

Although saliva contains various potential biomarkers that exhibit strong correlations with the concentrations in blood plasma or serum, the use of saliva as a diagnostic fluid has to date been relatively limited despite offering diverse opportunities. This review facilitates the recognition of these biomarker compounds, as well as the great advantages of saliva over blood and other bodily fluids, in order to encourage the future development of measurement assays for the detection of salivary components. In particular, we note that even when the assays are available for the detection of certain analytes, they have often not been applied to real or even artificial saliva samples. By providing essential knowledge of saliva, this review encourages the validation and the application of assays in saliva specimens.

In the collection of saliva for analysis, a large number of researches rely on cotton-based collection tools. However, we have demonstrated the potential interferences of cotton with the concentrations of analytes and highlighted that it is of critical importance to validate the applicability of the tool prior to analysis. The appropriate methods for storing the saliva specimens also need to be evaluated for different analytes under studies.

The list of potential salivary biomarkers was presented in Table 3. However, only a small number of electroanalytical assays are available for the detection of such analytes although electrochemistry offers many advantages especially in terms of quick and inexpensive measurements. User-friendly, portable electrochemical devices can be readily developed. One of the reasons for the lack of electrochemical applications in this field is likely the problems of poor selectivity of the assays without the uses of enzymes or antibodies. In this review, we have presented different approaches that can be employed to improve the selectivity of the electroanalytical measurements and to encourage the use of electroanalytical techniques in diagnostic applications.

\section{Conflicts of Interest}

There are no conflicts of interest to declare.

\section{Acknowledgements}

$\mathrm{KN}$ and KC receive funding from the Royal Thai government. This project is supported by the funding from the European Research Council under the European Union's Seventh 
Framework Programme (FP/2007-2013)/ERC Grant Agreement no. [320403]. We thank

Prof. Philip J. Cowen and Clare Williams for saliva collection and very helpful discussions.

\section{References}

1. V. de Almeida Pdel, A. M. Gregio, M. A. Machado, A. A. de Lima and L. R. Azevedo, J. Contemp. Dent. Pract., 2008, 9, 72-80.

2. J. L. Chicharro, A. Lucía, M. Pérez, A. F. Vaquero and R. Ureña, Sports Med., 2012, 26, 17-27.

3. M. D. Kaplan and B. J. Baum, Dysphagia, 1993, 8, 225-229.

4. B. L. Slomiany, V. L. N. Murty, J. Piotrowski and A. Slomiany, Gen. Pharmacol., 1996, 27, 761-771.

5. A. Bardow, D. Moe, B. Nyvad and B. Nauntofte, Arch. Oral Biol., 2000, 45, 1-12.

6. J. Kivelä, S. Parkkila, A.-K. Parkkila, J. Leinonen and H. Rajaniemi, J. Physiol., 1999, 520, 315-320.

7. H. Islas-Granillo, S. A. Borges-Yañez, C. E. Medina-Solís, C. A. Galan-Vidal, J. J. NavarreteHernández, M. Escoffié-Ramirez and G. Maupomé, West Indian Med. J., 2014, 63, 758-765.

8. B. S. Manjunatha, Textbook of Dental Anatomy and Oral Physiology, Jaypee Brothers,Medical Publishers Pvt. Limited, 2012.

9. $\quad$ H. Mese and R. Matsuo, J. Oral Rehabil., 2007, 34, 711-723.

10. S. J. Moss, J. Esthet. Restor. Dent., 1995, 7, 197-203.

11. J. K. M. Aps and L. C. Martens, Forensic Science International, 2005, 150, 119-131.

12. R. P. Shellis, Arch. Oral Biol., 1978, 23, 485-489.

13. V. W. H. Leung and B. W. Darvell, J. Dent., 1997, 25, 475-484.

14. K. Elagli, M. Traisnel and H. F. Hildebrand, Electrochim. Acta, 1993, 38, 1769-1774.

15. F. C. Giacomelli, C. Giacomelli and A. Spinelli, J. Braz. Chem. Soc., 2004, 15, 541-547.

16. J.-M. Meyer, Corros. Sci., 1977, 17, 971-982.

17. B. Levallois, Y. Fovet, L. Lapeyre and J. Y. Gal, Dental Materials, 1998, 14, 441-447.

18. J.-Y. Gal, Y. Fovet and M. Adib-Yadzi, Talanta, 2001, 53, 1103-1115.

19. J. Klimek, E. Hellwig and G. Ahrens, Caries Research, 1982, 16, 156-161.

20. H. NordbÖ, S. Darwish and R. S. Bhatnagar, Eur. J. Oral Sci., 1984, 92, 306-314.

21. K. Shibasaki, M. Kimura, R. Ikarashi, A. Yamaguchi and T. Watanabe, Metabolomics, 2012, 8, 484491.

22. M. Soukup, I. Biesiada, A. Henderson, B. Idowu, D. Rodeback, L. Ridpath, E. G. Bridges, A. M. Nazar and K. G. Bridges, Diabetol. Metab. Syndr., 2012, 4, 14-14.

23. O. Hershkovich and R. M. Nagler, Arch. Oral Biol., 2004, 49, 515-522.

24. E. De Corso, S. Baroni, S. Agostino, G. Cammarota, G. Mascagna, A. Mannocci, M. Rigante and J. Galli, Ann. Surg., 2007, 245, 880-885.

25. R. Venkatapathy, V. Govindarajan, N. Oza, S. Parameswaran, B. Pennagaram Dhanasekaran and K. V. Prashad, Int. J. Nephrol., 2014, 2014, 6.

26. S. Kumar, S. Padmashree and R. Jayalekshmi, Contemp. Clin. Dent., 2014, 5, 312-317.

27. S. Karjalainen, L. Sewón, E. Soderling, B. Larsson, I. Johansson, O. Simell, H. Lapinleimu and R. Seppänen, J. Dent. Res., 1997, 76, 1637-1643.

28. R. Segura, C. Javierre, J. L. Ventura, M. A. Lizarraga, B. Campos and E. Garrido, Br. J. Sports Med., 1996, 30, 305-309.

29. C. G. J. Schabmueller, D. Loppow, G. Piechotta, B. Schütze, J. Albers and R. Hintsche, Biosens. Bioelectron., 2006, 21, 1770-1776.

30. A. L. Mandel, C. Peyrot des Gachons, K. L. Plank, S. Alarcon and P. A. S. Breslin, PLoS One, 2010, 5, e13352.

31. A. Almståhl, M. Wikström and J. Groenink, Oral Microbiol. Immunol., 2001, 16, 345-352.

32. V. Ng, D. Koh, Q. Fu and S.-E. Chia, Clin. Chim. Acta, 2003, 338, 131-134.

33. S. Kejriwal, R. Bhandary, B. Thomas and S. Kumari, J. Clin. Diagn. Res., 2014, 8, ZC56-ZC60.

34. H. Tomita, S. Sato, R. Matsuda, Y. Sugiura, H. Kawaguchi, T. Niimi, S. Yoshida and M. Morishita, Lung, 1999, 177, 161-167.

35. L. Manetti, G. Rossi, L. Grasso, V. Raffaelli, I. Scattina, S. Del Sarto, M. Cosottini, A. Iannelli, M. Gasperi, F. Bogazzi and E. Martino, Eur. J. Endocrinol., 2013, 168, 315-321.

36. M. Yasuda, S. Honma, K. Furuya, T. Yoshii, Y. Kamiyama, H. Ide, S. Muto and S. Horie, J. Mens Health, 2008, 5, 56-63.

37. Y. C. Lu, G. R. Bentley, P. H. Gann, K. R. Hodges and R. T. Chatterton, Fertil. Steril., 1999, 71, 863868. 
38. M. Somogyi, J. Biol. Chem., 1938, 125, 399-414.

39. B. S. Henson and D. T. Wong, in Oral Biology: Molecular Techniques and Applications, eds. G. J. Seymour, M. P. Cullinan and N. C. K. Heng, Humana Press, Totowa, NJ, 2010, DOI: 10.1007/978-160761-820-1_2, pp. 21-30.

40. C. Golatowski, M. Gesell Salazar, V. M. Dhople, E. Hammer, T. Kocher, N. Jehmlich and U. Völker, Clin. Chim. Acta, 2013, 419, 42-46.

41. M. Navazesh and S. K. S. Kumar, J. Am. Dent. Assoc., 2008, 139, 35S-40S.

42. J. C. J. Kjeilen, P. Brodin, H. Aars and T. Berg, Acta Physiol. Scand., 1987, 131, 169-175.

43. D. A. Granger, E. B. Schwartz, A. Booth, M. Curran and D. Zakaria, Psychoneuroendocrinology, 1999, 24, 567-579.

44. D. A. Froehlich, R. M. Pangborn and J. R. Whitaker, Physiol. Behav., 1987, 41, 209-217.

45. E. A. Shirtcliff, D. A. Granger, E. Schwartz and M. J. Curran, Psychoneuroendocrinology, 2001, 26, 165-173.

46. R. L. Hodinka, T. Nagashunmugam and D. Malamud, Clin. Diagn. Lab. Immunol., 1998, 5, 419-426.

47. K. Ngamchuea, C. Batchelor-McAuley, P. J. Cowen, C. Williams, L. M. Goncalves and R. G. Compton, The Analyst, 2016, 141, 4707-4712.

48. $\quad$ R. Haeckel, Ann. N.Y. Acad. Sci., 1993, 694, 128-142.

49. M. Navazesh, Ann. N.Y. Acad. Sci., 1993, 694, 72-77.

50. K. Hanrahan, A. M. McCarthy, C. Kleiber, S. Lutgendorf and E. Tsalikian, Appl. Nurs. Res., 2006, 19, 95-101.

51. Z. S. Czégény, J. L. Chicharro, P. Fernández, A. Gutiérrez and C. Cámara, Biol. Trace Elem. Res., 2001, 79, 131-137.

52. $\quad$ F. I. Daniel, L. Lima and C. R. d. Santos, Braz. J. Pharm. Sci., 2016, 52, 679-684.

53. A. H. Garde and Å. M. Hansen, Scand. J. Clin. Lab. Invest., 2005, 65, 433-436.

54. D. Esser, G. Alvarez-Llamas, M. P. de Vries, D. Weening, R. J. Vonk and H. Roelofsen, Biomarker Insights, 2008, 3, 25-27.

55. A. Nurkka, J. Obiero, H. Kayhty and J. A. G. Scott, Clin. Vaccine Immunol., 2003, 10, 357-361.

56. M. Gröschl, R. Wagner, M. Rauh and H. G. Dörr, Steroids, 2001, 66, 737-741.

57. G.-L. S. Whembolua, D. A. Granger, S. Singer, K. T. Kivlighan and J. A. Marguin, Horm. Behav., 2006, 49, 478-483.

58. G. F. Read, Ann. N.Y. Acad. Sci., 1993, 694, 146-160.

59. J. T. Wilson, Ann. N.Y. Acad. Sci., 1993, 694, 48-61.

60. I. D. Mandel, Ann. N.Y. Acad. Sci., 1993, 694, 1-10.

61. K. H. Zou, K. Tuncali and S. G. Silverman, Radiology, 2003, 227, 617-622.

62. T. A. Lang and M. Secic, How to Report Statistics in Medicine: Annotated Guidelines for Authors, Editors, and Reviewers, American College of Physicians, 2006.

63. K. M. Ramachandran and C. P. Tsokos, Mathematical Statistics with Applications, Elsevier Science, 2009.

64. M. Jarvis, P. Primatesta, B. Erens, C. Feyerabend and A. Bryant, Nicotine Tobacco Res., 2003, 5, 349355.

65. J. T. Bernert, J. E. McGuffey, M. A. Morrison and J. L. Pirkle, J. Anal. Toxicol., 2000, 24, 333-339.

66. F. Kardani, A. Daneshfar and R. Sahrai, J. Chromatogr. B Analyt. Technol. Biomed. Life Sci., 2010, 878, 2857-2862.

67. J. E. Rose, E. D. Levin and N. Benowitz, Ther. Drug Monit., 1993, 15, 431-435.

68. D. Forman, S. Al-Dabbagh and R. Doll, Nature, 1985, 313, 620-625.

69. G. A. Sanchez, V. A. Miozza, A. Delgado and L. Busch, Nitric Oxide, 2014, 36, 31-35.

70. A. Wahllnder, S. Mohr and G. Paumgartner, J. Hepatol., 1990, 10, 129-137.

71. J. A. Carrillo, M. Christensen, S. I. Ramos, C. Alm, M. L. Dahl, J. Benitez and L. Bertilsson, Ther. Drug Monit., 2000, 22, 409-417.

72. $\quad$ E. Zylber-Katz, L. Granit and M. Levy, Clin. Pharmacol. Ther., 1984, 36, 133-137.

73. H. N. Alkaysi, M. S. Salem and Y. M. El-Sayed, J. Clin. Phar. Ther., 1988, 13, 109-115.

74. T. F. Maliszewski and D. E. Bass, J. Appl. Physiol., 1955, 8, 289-291.

75. L. Minarowski, D. Sands, A. Minarowska, A. Karwowska, A. Sulewska, M. Gacko and E. Chyczewska, Folia Histochem. Cytobiol., 2008, 46, 245-246.

76. G. Almadori, F. Bussu, J. Galli, A. Limongelli, S. Persichilli, B. Zappacosta, A. Minucci, G. Paludetti and B. Giardina, Head Neck, 2007, 29, 648-654.

77. A. R. Shivashankara and M. K. Prabhu, Biomed Res-India, 2011, 22, 355-359.

78. C. Arana, A. Cutando, M. J. Ferrera, G. Gomez-Moreno, C. V. Worf, M. J. Bolanos, G. Escames and D. Acuna-Castroviejo, J. Oral Pathol. Med., 2006, 35, 554-559.

79. J. F. Bates, R. E. Hughes and R. J. Hurley, Arch. Oral Biol., 1972, 17, 1017-1020. 
80. J. Giebultowicz, P. Wroczynski and D. Samolczyk-Wanyura, J. Oral Pathol. Med., 2011, 40, 726-730.

81. B. Owen-Smith, J. Quiney and J. Read, The Lancet, 1998, 351, 1932.

82. M. Zloczower, A. Z. Reznick, R. O. Zouby and R. M. Nagler, Antioxid. Redox Signal., 2007, 9, 765773.

83. M. Soukup, I. Biesiada, A. Henderson, B. Idowu, D. Rodeback, L. Ridpath, E. G. Bridges, A. M. Nazar and K. G. Bridges, Diabetol. Metab. Syndr., 2012, 4, 14.

84. J. J. McAuliffe, A. L. Sherwin, I. E. Leppik, S. A. Fayle and C. E. Pippenger, Neurology, 1977, 27, 409-413.

85. C. Knott and F. Reynolds, Ther. Drug Monit., 1984, 6, 35-41.

86. R. F. Goldsmith and R. A. Ouvrier, Ther. Drug Monit., 1981, 3, 151-157.

87. D. Schmidt and H. J. Kupferberg, Epilepsia, 1975, 16, 735-741.

88. $\quad$ S. P. Galant, Arch. Pediatr. Adolesc. Med., 1977, 131, 970.

89. M. Aviram, A. Tal, Z. Benzvi and R. Gorodischer, Pediatrics, 1987, 80, 894-897.

90. G. Levy, E. F. Ellis and R. Koysooko, Pediatrics, 1974, 53, 873-876.

91. C. Knott, M. Bateman and F. Reynolds, Br. J. Clin. Pharmacol., 1984, 17, 9-14.

92. H. Wade, D. L. McCoubrie, D. M. Fatovich, J. Ryan, S. Vasikaran and F. F. Daly, Clin. Toxicol. (Phila.), 2008, 46, 534-538.

93. R. Perry, M. Campbell, D. M. Grega and L. Anderson, J. Clin. Psychopharmacol., 1984, 4, 199-202.

94. J. L. Evrard, P. Baumann, R. Pera-Bally and L. Peters-Haefeli, Acta Psychiatr. Scand., 1978, 58, 67-79.

95. $\quad$ L. C. Degutis, Acad. Emerg. Med., 2004, 11, 885-887.

96. $\quad$ W. Gubala and D. Zuba, Pol. J. Pharmacol., 2002, 54, 161-165.

97. G.-c. Tu, B. Kapur and Y. Israel, Alcohol.: Clin. Exp. Res., 1992, 16, 222-227.

98. M. E. Bates and C. S. Martin, J. Stud. Alcohol, 1997, 58, 531-538.

99. $\quad$ E. J. Cone, K. Kumor, L. K. Thompson and M. Sherer, J. Anal. Toxicol., 1988, 12, 200-206.

100. L. K. Thompson, D. Yousefnejad, K. Kumor, M. Sherer and E. J. Cone, J. Anal. Toxicol., 1987, 11, 3638.

101. C. W. Gorodetzky and M. P. Kullberg, Clin. Pharmacol. Ther., 1974, 15, 579-587.

102. W.-L. Wang, W. D. Darwin and E. J. Cone, J. Chromatogr. B: Biomed. Sci. Appl., 1994, 660, $279-290$.

103. A. J. Jenkins, J. M. Oyler and E. J. Cone, J. Anal. Toxicol., 1995, 19, 359-374.

104. J. L. Valentine and P. Psaltis, Anal. Lett., 1979, 12, 855-866.

105. R. S. Niedbala, K. W. Kardos, D. F. Fritch, S. Kardos, T. Fries, J. Waga, J. Robb and E. J. Cone, J. Anal. Toxicol., 2001, 25, 289-303.

106. S. Strano-Rossi, C. Colamonici and F. Botre, Anal. Chim. Acta, 2008, 606, 217-222.

107. P. Strickland, R. Morriss, A. Wearden and B. Deakin, J. Affect. Disord., 1998, 47, 191-194.

108. K. Vedhara, J. Miles, P. Bennett, S. Plummer, D. Tallon, E. Brooks, L. Gale, K. Munnoch, C. Schreiber-Kounine, C. Fowler, S. Lightman, A. Sammon, Z. Rayter and J. Farndon, Biol. Psychol., 2003, 62, 89-96.

109. J.-P. Kahn, D. R. Rubinow, C. L. Davis, M. Kling and R. M. Post, Biol. Psychiatry, 1988, 23, 335-349.

110. R. F. Vining, R. A. McGinley, J. J. Maksvytis and K. Y. Ho, Ann. Clin. Biochem., 1983, 20 (Pt 6), 329335.

111. U. Teruhisa, H. Ryoji, I. Taisuke, S. Tatsuya, M. Fumihiro and S. Tatsuo, Clin. Chim. Acta, 1981, 110, 245-253.

112. J. D. Few, P. J. W. Wallis and V. H. T. James, Clin. Endocrinol. (Oxf.), 1986, 24, 119-126.

113. R. McVie, L. S. Levine and M. I. New, Pediatr. Res., 1979, 13, 755-759.

114. F. S. Khan-Dawood, J. K. Choe and M. Y. Dawood, Am. J. Obstet. Gynecol., 1984, 148, 442-445.

115. T. Ohzeki, B. Manella, G. Campo, uuml, D. belin and M. Zachmann, Hormone Res., 1991, 36, 235237.

116. S. G. Johnson, G. F. Joplin and J. M. Burrin, Clin. Chim. Acta, 1987, 163, 309-318.

117. C. Wang, S. Plymate, E. Nieschlag and C. A. Paulsen, J. Clin. Endocrinol. Metab., 1981, 53, 10211024.

118. R. F. Walker, I. A. Hughes and D. Riad-Fahmy, Clin. Endocrinol. (Oxf.), 1979, 11, 631-637.

119. M. Zerah, S. Y. Pang and M. I. New, J. Clin. Endocrinol. Metab., 1987, 65, 227-232.

120. L. A. Perry, N. Wathen and T. Chard, Horm. Metab. Res., 1987, 19, 444-447.

121. J. K. Choe, F. S. Khan-Dawood and M. Yusoff-Dawood, Am. J. Obstet. Gynecol., 1983, 147, 557-562.

122. L. J. Tivis, M. D. Richardson, E. Peddi and B. Arjmandi, Prog. Neuropsychopharmacol. Biol. Psychiatry, 2005, 29, 727-732.

123. L. D. Belkien, J. Bordt, P. Möller, R. Hano and E. Nieschlag, Fertil. Steril., 1985, 44, 322-327.

124. J. J. Evans, A. R. Wilkinson and D. R. Aickin, Clin. Chem., 1984, 30, 120-121.

125. M. S. Preti, S. Lodi, P. Busacchi, M. Filicori and C. Flamigni, Steroids, 1984, 43, 469-479.

126. N. Kundu, N. Novak and L. P. Petersen, Steroids, 1983, 41, 145-153. 
127. J. Pasic and J. C. Pickup, Diabetes Care, 1988, 11, 489-494.

128. M.-L. Laakso, T. Porkka-Heiskanen, A. Alila, D. Stenberg and G. Johansson, J. Pineal Res., 1990, 9, 39-50.

129. R. Nowak, I. C. McMillen, J. Redman and R. V. Short, Clin. Endocrinol. (Oxf.), 1987, 27, 445-452.

130. A. Voultsios, D. J. Kennaway and D. Dawson, J. Biol. Rhythms, 1997, 12, 457-466.

131. $\quad$ R. R. Frerichs, M. T. Htoon, N. Eskes and S. Lwin, The Lancet, 1992, 340, 1496-1499.

132. C. J. Major, S. E. Read, R. A. Coates, A. Francis, B. J. McLaughlin, M. Millson, F. Shepherd, M. Fanning, L. Calzavara, D. MacFadden and et al., J. Infect. Dis., 1991, 163, 699-702.

133. K. B. Elkon, A. E. Gharavi, B. M. Patel, G. R. Hughes and A. Frankel, Clin. Exp. Immunol., 1983, 52, 75-84.

134. D. J. Bradshaw and P. D. Marsh, Caries Res., 1998, 32, 456-462.

135. E. K. Silbergeld, Ann. N.Y. Acad. Sci., 1993, 694, 62-71.

136. D. B. P. Goodman, Ann. N.Y. Acad. Sci., 1993, 694, 78-85.

137. C. Kirschbaum and D. H. Hellhammer, Psychoneuroendocrinology, 1994, 19, 313-333.

138. A. Kaushik, A. Vasudev, S. K. Arya, S. K. Pasha and S. Bhansali, Biosens. Bioelectron., 2014, 53, 499512.

139. M. Groschl and M. Rauh, Steroids, 2006, 71, 1097-1100.

140. J. Guechot, J. Fiet, P. Passa, J. M. Villette, B. Gourmel, F. Tabuteau, G. Cathelineau and C. Dreux, Horm. Res., 1982, 16, 357-364.

141. D. W. Archibald and G. A. Cole, AIDS Res. Hum. Retroviruses, 1990, 6, 1425-1432.

142. A. D. Harries, D. Maher, S. Graham, S. T. Initiative, W. H. O. D. o. HIV/AIDS., W. H. O. D. o. Child, A. Health and Development, TB/HIV: A Clinical Manual, World Health Organization, 2004.

143. M. Raffa, S. Barhoumi, F. Atig, C. Fendri, A. Kerkeni and A. Mechri, Prog. Neuropsychopharmacol. Biol. Psychiatry, 2012, 39, 371-375.

144. F. Tietze, Anal. Biochem., 1969, 27, 502-522.

145. H. Güntherberg and J. Rost, Anal. Biochem., 1966, 15, 205-210.

146. O. W. Griffith, Anal. Biochem., 1980, 106, 207-212.

147. I. H. Shaik and R. Mehvar, Anal. Bioanal. Chem., 2006, 385, 105-113.

148. K. Ngamchuea, C. Batchelor-McAuley and R. G. Compton, Anal. Chem., 2017, 89, 2901-2908.

149. D. J. Reed, J. R. Babson, P. W. Beatty, A. E. Brodie, W. W. Ellis and D. W. Potter, Anal. Biochem., 1980, 106, 55-62.

150. B. A. Neuschwander-Tetri and F. J. Roll, Anal. Biochem., 1989, 179, 236-241.

151. V. Serru, B. Baudin, F. Ziegler, J. P. David, M. J. Cals, M. Vaubourdolle and N. Mario, Clin. Chem., 2001, 47, 1321-1324.

152. C. Carru, A. Zinellu, G. Mario Pes, G. Marongiu, B. Tadolini and L. Deiana, Electrophoresis, 2002, 23, 1716.

153. Z. Chen, Z. Wang, J. Chen, S. Wang and X. Huang, The Analyst, 2012, 137, 3132-3137.

154. H.-Y. Han, Z.-K. He and Y.-E. Zeng, Microchim. Acta, 2006, 155, 431-434.

155. J. C. Harfield, C. Batchelor-McAuley and R. G. Compton, The Analyst, 2012, 137, 2285.

156. P. T. Lee, L. M. Goncalves and R. G. Compton, Sens. Actuators, B, 2015, 221, 962-968.

157. S. A. Zaidi and J. H. Shin, Anal. Methods, 2016, 8, 1745-1754.

158. K. Ngamchuea, C. Lin, C. Batchelor-McAuley and R. G. Compton, Anal. Chem., 2017, 89, 3780-3786.

159. A. R. Rosa, N. Singh, E. Whitaker, M. de Brito, A. M. Lewis, E. Vieta, G. C. Churchill, J. R. Geddes and G. M. Goodwin, Psychol. Med., 2014, 44, 2409-2418.

160. J. P. Richie, Jr., L. Skowronski, P. Abraham and Y. Leutzinger, Clin. Chem., 1996, 42, 64-70.

161. J. W. Gawryluk, J. F. Wang, A. C. Andreazza, L. Shao and L. T. Young, Int. J. Neuropsychopharmacol., 2011, 14, 123-130.

162. O. K. Tuncel, G. Sarisoy, B. Bilgici, O. Pazvantoglu, E. Cetin, E. Unverdi, B. Avci and O. Boke, Psychiatry Res., 2015, 228, 688-694.

163. J. Lagopoulos, D. F. Hermens, J. Tobias-Webb, S. Duffy, S. L. Naismith, D. White, E. Scott and I. B. Hickie, J. Psychiatr. Res., 2013, 47, 412-417.

164. B. R. Godlewska, S. W. Yip, J. Near, G. M. Goodwin and P. J. Cowen, Psychopharmacology (Berl.), 2014, 231, 327-332.

165. R. Kand'ar, P. Zakova, H. Lotkova, O. Kucera and Z. Cervinkova, J. Pharm. Biomed. Anal., 2007, 43, 1382-1387.

166. A. M. Cantin, S. L. North, R. C. Hubbard and R. G. Crystal, J. Appl. Physiol., 1987, 63, $152-157$.

167. F. R. Ochseedorf, R. Buhl, A. Bastlein and H. Beschmann, Hum. Reprod., 1998, 13, 353-359.

168. D. P. Jones, J. L. Carlson, P. S. Samiec, P. Sternberg, V. C. Mody, R. L. Reed and L. A. S. Brown, Clin. Chim. Acta, 1998, 275, 175-184. 
169. E. Emekli-Alturfan, A. Yarat, E. Caliskan-Ak, R. Pisiriciler, B. Kuru and U. Noyan, J. Clin. Lab. Anal., 2013, 27, 261-266.

170. L. von Knorring and H. Mörnstad, Neuropsychobiology, 2008, 15, 146-154.

171. M. J. Larsen, A. F. Jensen, D. M. Madsen and E. I. F. Pearce, Arch. Oral Biol., 1999, 44, 111-117.

172. M. J. Levine, Ann. N.Y. Acad. Sci., 1993, 694, 11-16.

173. C. B. Jacobs, M. J. Peairs and B. J. Venton, Anal. Chim. Acta, 2010, 662, 105-127.

174. C. Hsueh, R. Bravo, A. J. Jaramillo and A. Brajter-Toth, Anal. Chim. Acta, 1997, 349, 67-76.

175. P. T. Lee, D. Lowinsohn and R. G. Compton, Electroanalysis, 2014, 26, 1488-1496.

176. M. C. Henstridge, E. J. F. Dickinson, M. Aslanoglu, C. Batchelor-McAuley and R. G. Compton, Sens. Actuators, B, 2010, 145, 417-427.

177. K. R. Kneten and R. L. McCreery, Anal. Chem., 2002, 64, 2518-2524.

178. R. L. McCreery, Electroanal. Chem., 1991, 17, 221-374.

179. H. D. Schwartz, Clin. Chim. Acta, 1975, 64, 227-239.

180. S. M. Friedman, S. L. Wong and J. H. Walton, J. Appl. Physiol., 1963, 18, 950-954.

181. C. R. Raj, T. Okajima and T. Ohsaka, J. Electroanal. Chem., 2003, 543, 127-133.

182. P. T. Lee and R. G. Compton, Anal. Sci., 2015, 31, 685-691.

183. P. T. Lee, D. Lowinsohn and R. G. Compton, Sensors (Basel), 2014, 14, 10395-10411.

184. P. T. Lee and R. G. Compton, Sens. Actuators, B, 2015, 209, 983-988.

185. J. Ellison, C. Batchelor-McAuley, K. Tschulik and R. G. Compton, Sens. Actuators, B, 2014, 200, 4752.

186. J. R. Windmiller and J. Wang, Electroanalysis, 2013, 25, 29-46.

187. S. Berchmans, R. Karthikeyan, S. Gupta, G. E. J. Poinern, T. B. Issa and P. Singh, Sens. Actuators, B, 2011, 160, 1224-1231.

188. M. F. Alecrim, F. M. Oliveira, T. J. Guedes, C. D. c. Neves, V. A. Mendonça, E. S. Gil, R. M. Verly and W. T. P. dos Santos, Electrochim. Acta, 2016, 222, 331-337.

189. H. Nian, J. Wang, H. Wu, J. G. Lo, K. H. Chiu, J. G. Pounds and Y. Lin, Anal. Chim. Acta, 2012, 713, 50-55.

190. S.-J. Wang, H.-W. Liaw and Y.-C. Tsai, Electrochem. Commun., 2009, 11, 733-735.

191. C. T. Wu, P. Y. Chen, J. G. Chen, V. Suryanarayanan and K. C. Ho, Anal. Chim. Acta, 2009, 633, 119126.

192. M. J. Sims, N. V. Rees, E. J. F. Dickinson and R. G. Compton, Sens. Actuators, B, 2010, 144, $153-158$.

193. L. Highton, R. O. Kadara, N. Jenkinson, B. Logan Riehl and C. E. Banks, Electroanalysis, 2009, 21, 2387-2389.

194. L'. Švorc, D. M. Stanković and K. Kalcher, Diamond Relat. Mater., 2014, 42, 1-7.

195. K. Liu, W. Z. Wei, J. X. Zeng, X. Y. Liu and Y. P. Gao, Anal. Bioanal. Chem., 2006, 385, 724-729.

196. S. Ward-Jones, C. E. Banks, A. O. Simm, L. Jiang and R. G. Compton, Electroanalysis, 2005, 17, 1806-1815.

197. M. Badea, A. Amine, G. Palleschi, D. Moscone, G. Volpe and A. Curulli, J. Electroanal. Chem., 2001, 509, 66-72.

198. S. I. R. Malha, J. Mandli, A. Ourari and A. Amine, Electroanalysis, 2013, 25, 2289-2297.

199. J. Davis, K. J. McKeegan, M. F. Cardosi and D. H. Vaughan, Talanta, 1999, 50, 103-112.

200. A. C. Torres, M. M. Barsan and C. M. Brett, Food Chem., 2014, 149, 215-220.

201. G. A. M. Mersal, Food Anal. Methods, 2011, 5, 520-529.

202. X. Kan, T. Liu, C. Li, H. Zhou, Z. Xing and A. Zhu, J. Solid State Electrochem., 2012, 16, 3207-3213.

203. B. Habibi, M. Abazari and M. H. Pournaghi-Azar, Chin. J. Catal., 2012, 33, 1783-1790.

204. R. N. Goyal, S. Bishnoi and B. Agrawal, J. Electroanal. Chem., 2011, 655, 97-102.

205. P. Yang, W. Wei and C. Tao, Anal. Chim. Acta, 2007, 585, 331-336.

206. J. S. Easow, P. Gnanaprakasam and T. Selvaraju, Res. Chem. Intermed., 2015, 42, 2539-2551.

207. A. Safavi, N. Maleki, E. Farjami and F. A. Mahyari, Anal. Chem., 2009, 81, 7538-7543.

208. J. C. Ndamanisha, J. Bai, B. Qi and L. Guo, Anal. Biochem., 2009, 386, 79-84.

209. P. T. Lee, K. R. Ward, K. Tschulik, G. Chapman and R. G. Compton, Electroanalysis, 2014, 26, 366373.

210. N. Lawrence, J. Davis and R. G. Compton, Talanta, 2001, 53, 1089-1094.

211. F. Ricci, F. Arduini, C. S. Tuta, U. Sozzo, D. Moscone, A. Amine and G. Palleschi, Anal. Chim. Acta, 2006, 558, 164-170.

212. D. Lowinsohn, P. T. Lee and R. G. Compton, Int. J. Electrochem. Sci., 2014, 9, 3458-3472.

213. P. T. Lee and R. G. Compton, Electroanalysis, 2013, 25, 1613-1620.

214. C. L. Sun, H. H. Lee, J. M. Yang and C. C. Wu, Biosens. Bioelectron., 2011, 26, 3450-3455.

215. Z. H. Sheng, X. Q. Zheng, J. Y. Xu, W. J. Bao, F. B. Wang and X. H. Xia, Biosens. Bioelectron., 2012, 34, 125-131. 
216. S. Zhu, H. Li, W. Niu and G. Xu, Biosens. Bioelectron., 2009, 25, 940-943.

217. R. Zhang, G.-D. Jin, D. Chen and X.-Y. Hu, Sens. Actuators, B, 2009, 138, 174-181.

218. J. C. Fanguy and C. S. Henry, Electrophoresis, 2002, 23, 767-773.

219. J. M. Zen and P. J. Chen, Anal. Chem., 1997, 69, 5087-5093.

220. A. Safavi, N. Maleki, O. Moradlou and F. Tajabadi, Anal. Biochem., 2006, 359, 224-229.

221. K. Shi and K.-K. Shiu, Electroanalysis, 2001, 13, 1319-1325.

222. Y.-H. Zhu, Z.-L. Zhang and D.-W. Pang, J. Electroanal. Chem., 2005, 581, 303-309.

223. Y. Li, S. Wu, P. Luo, J. Liu, G. Song, K. Zhang and B. Ye, Anal. Sci., 2012, 28, 497-502.

224. G. J. Yang, K. Wang, J. J. Xu and H. Y. Chen, Anal. Lett., 2007, 37, 629-643.

225. H. Yin, X. Meng, H. Su, M. Xu and S. Ai, Food Chem., 2012, 134, 1225-1230.

226. J. Zen, Talanta, 1999, 50, 635-640.

227. Y. Fan, J. H. Liu, H. T. Lu and Q. Zhang, Colloids Surf. B. Biointerfaces, 2011, 85, 289-292.

228. J. Li, J. Liu, G. Tan, J. Jiang, S. Peng, M. Deng, D. Qian, Y. Feng and Y. Liu, Biosens. Bioelectron., 2014, 54, 468-475.

229. B. G. Mahmoud, M. Khairy, F. A. Rashwan and C. E. Banks, Anal. Chem., 2017, 89, 2170-2178.

230. X. Chen, J. Zhu, Q. Xi and W. Yang, Sens. Actuators, B, 2012, 161, 648-654.

231. M. Amiri-Aref, J. B. Raoof and R. Ojani, Colloids Surf. B. Biointerfaces, 2013, 109, 287-293.

232. A. Kutluay and M. Aslanoglu, Anal. Chim. Acta, 2014, 839, 59-66.

233. R. T. Kachoosangi, G. G. Wildgoose and R. G. Compton, Anal. Chim. Acta, 2008, 618, 54-60.

234. X. Kang, J. Wang, H. Wu, J. Liu, I. A. Aksay and Y. Lin, Talanta, 2010, 81, 754-759.

235. K. Chaisiwamongkhol, C. Batchelor-McAuley and R. G. Compton, The Analyst, 2017, 142, 28282835.

236. F. Contu, M. Vega-Arroyo and S. R. Taylor, Int. J. Mater. Sci., 2014, 4, 8-13.

237. C. Zuliani, G. Matzeu and D. Diamond, Electrochim. Acta, 2014, 132, 292-296.

238. D.-M. Kim, S. J. Cho, C.-H. Cho, K. B. Kim, M.-Y. Kim and Y.-B. Shim, Biosens. Bioelectron., 2016, 79, 165-172. 